\title{
CREDITOR CLAIMS IN ARBITRATION AND IN COURT
}

\author{
Christopher R. Drahozal* and Samantha Zyontz**
}

\section{INTRODUCTION}

In July 2009, the world of debt collection arbitration was turned upside down. ${ }^{1} \quad$ In settlement of a lawsuit brought by the Minnesota Attorney General alleging fraud and deceptive practices, ${ }^{2}$ the National Arbitration Forum (NAF) on July 17, 2009, agreed permanently to stop administering new consumer arbitrations. ${ }^{3}$ The NAF was far and away the largest provider of debt collection arbitration services, having administered an estimated 214,000 debt collection cases in 2006. ${ }^{4}$

* John M. Rounds Professor of Law and Associate Dean for Research \& Faculty Development, University of Kansas School of Law.

** Senior Research Associate, Searle Civil Justice Institute, George Mason University School of Law. We are grateful to the Searle Civil Justice Institute and the University of Kansas School of Law for their support, financial and otherwise, for this project. We very much appreciate the cooperation of the American Arbitration Association, especially Bill Slate, Richard Naimark, Ryan Boyle, India Johnson, and Eric Tuchmann. Thanks to Henry Butler and Geoff Lysaught for their oversight and encouragement. Jon Klick, Jason Johnston, Ron Allen, and Josh Wright, as well as members of the Searle Board of Overseers, provided helpful comments on this project and on drafts of this article. Richard Hynes graciously shared his data on debt collection cases in Virginia state courts, and Thomas Cohen and Nicole Waters answered our questions on the availability of state court data. Thanks also to Elise Nelson and Matthew Sibery for their help in compiling and processing the data and in ensuring the accuracy of this article.

1. The vast majority of cases arising out of disputes between businesses and consumers, both in court and in arbitration, involve claims by creditors seeking to recover amounts allegedly owed by the consumers. Colloquially, court cases arising out of such claims are referred to as "debt collection litigation," while arbitrations are referred to as "debt collection arbitration." We use those phrases in this article because they are in common usage in the public policy arena. See generally, e.g., FEDERAL Trade Comm'n, Repairing a Broken System: Protecting Consumers in DebT Collection LITIGATION AND ARBITRATION (July 2010), available at http://www.ftc.gov/os/2010/07/debtcollection report.pdf. By using the phrases, we do not mean to suggest that the amounts sought to be recovered necessarily are owed by the consumers-i.e., that they are, in fact, debts of the consumer defendant or respondent.

2. Complaint at 3, Minnesota v. National Arbitration Forum, Inc., No. 27-CV-09-18559 (Minn. Dist. Ct. July 14, 2009), available at http://www.ag.state.mn.us/PDF/PressReleases/SignedFiled ComplaintArbitrationCompany.pdf [hereinafter Minnesota Complaint].

3. Consent Judgment, ฯ 3, Minnesota v. National Arbitration Forum, Inc., No. 27-CV-09-18559 (Minn. Dist. Ct. July 17, 2009), available at http://pubcit.typepad.com/files/nafconsentdecree.pdf.

4. Minnesota Complaint, supra note 2, 980 , at 29. 
Shortly thereafter, the American Arbitration Association (AAA) announced that it was imposing a moratorium on its own administration of most consumer debt collection cases. ${ }^{5}$ The AAA did not impose its moratorium in response to pending litigation, ${ }^{6}$ but rather did so based on its "experiences administering debt collection arbitrations" and "its consideration of a number of policy concerns that have been raised." 7 The moratorium extends to the following types of cases:

[C]onsumer debt collection programs or bulk filings and individual case filings in which the company is the filing party and the consumer has not agreed to arbitrate at the time of the dispute and the case involves a credit card bill or, the case involves a telecom bill or the case involves a consumer finance matter. ${ }^{8}$

The AAA continues to administer individual claims brought by other creditors against consumers, such as claims by law firms and accounting firms seeking to recover unpaid fees, as well as cases involving a telecom bill, credit card bill, or other consumer finance matter that arises out of a post-dispute agreement to arbitrate.

This article examines the outcomes of AAA debt collection arbitrations (in cases resolved prior to the moratorium), as well as the outcomes of debt collection cases in court. The potential implications of this research are twofold. First, it provides possible insights into how consumers might fare if debt collection cases are resolved in court instead of in arbitration. Many consumer arbitration clauses continue to provide for NAF or AAA arbitration. To evaluate whether consumers might be better off if debt collection claims arising out of those contracts are resolved in court instead of arbitration, a comparison of creditor claims in arbitration and in court is necessary.

Second, and more importantly, it adds new information to the policy debate over consumer arbitration. The most commonly cited studies of asserted bias in consumer arbitration examine outcomes in debt collection arbitrations. ${ }^{9}$ Some critics of consumer arbitration assert that the high win

5. Press Release, American Arbitration Association, The American Arbitration Association Calls for Reform of Debt Collection Arbitration (July 23, 2009), available at http://www.adr.org/si.asp?id=5769.

6. Id.

7. Arbitration or Arbitrary: The Misuse of Mandatory Arbitration to Collect Consumer Debts: Hearing Before the Subcomm. on Domestic Policy of the H. Comm. On Oversight, 111th Cong. (July 22, 2009) (testimony of Richard W. Naimark on Behalf of the American Arbitration Association), available at http://oversight.house.gov/images/stories/documents/20090722112616.pdf.

8. Notice on Consumer Debt Collection Arbitrations, AMERICAN ARbitration Association, http://www.adr.org/sp.asp?id=36427 (last visited Oct. 27, 2009).

9. See, e.g., PUblic Citizen, The ARbitration Trap: How Credit Card Companies ENSNARE CONSUMERS (Sept. 2007), available at http://www.citizen.org/documents/ArbitrationTrap.pdf (studying arbitrations administered by the National Arbitration Forum); see also SEARLE CIVIL JUSTICE INST., CONSUMER ARBITRATION BEFORE THE AMERICAN ARBITRATION ASSOCIATION: PRELIMINARY REPORT 115 app. 1 (Mar. 2009) (summarizing studies), available at http://www.law.northwestern.edu/ searlecenter/uploads/Consumer\%20Arbitration\%20full_report.pdf; Christopher R. Drahozal \& Samantha Zyontz, Consumer Arbitration Before the American Arbitration Association, 25 ОHIO J. ON 
rate of business claimants in such cases alone shows that arbitration is biased in favor of businesses. ${ }^{10}$ Others compare the win rate of business claimants in arbitration to the win rate of consumer claimants in arbitration, concluding that the higher win rate of business claimants provides evidence of bias. ${ }^{11}$

These numbers do not in themselves show that arbitration is a biased means of resolving consumer disputes. Despite suggestions to the contrary, a high win rate for business claimants does not alone show bias. The win rate is only meaningful in comparison to some baseline. ${ }^{12}$ A fifty percent win rate for claimants may be extremely high if claimants bringing similar claims tend to win at a lower rate in court, or extremely low if claimants bringing similar claims tend to win at a higher rate in court. The same is true of a ninety-percent win rate or even a ninety-nine percent win rate.

Nor does comparing the win rates of business claimants to the win rates of consumer claimants provide evidence of bias in arbitration. As we have explained elsewhere, the differing win rates for business claimants and consumer claimants appear to result from two factors, neither of which provides evidence of bias. ${ }^{13}$ First, the types of claims businesses bring in arbitration tend to differ from the types of claims consumers bring. ${ }^{14}$

DISP. RESOL. _ (forthcoming 2010). We have not studied arbitrations administered by the NAF, and offer no opinions on those arbitrations.

10. E.g., Letter from Professors of Consumer Law and Banking Law to Senators Dodd and Shelby and Congressmen Frank and Bachus, Statement in Support of Legislation Creating a Consumer Financial Protection Agency 6 (Sept. 29, 2009), available at http://law.hofstra.edu/pdf/Media/ consumer-law\%209-28-09.pdf ("Studies have found the arbitrators find for companies against consumers 94 to $96 \%$ of the time, suggesting that arbitration providers are responding to the incentive to find for those who select them: the companies that insert their names in their form contracts.”; Elizabeth Warren, Deathstar Arbitration, CREDIT SLIPS (Sept. 27, 2007, 3:55 PM), http://www.creditslips.org/creditslips/2007/09/deathstar-arbit.html\#more ("The data suggest, however, that [arbitration] is Darth Vader's Death Star-the Empire always wins.”).

11. E.g., Federal Arbitration Act: Is the Credit Card Industry Using It to Quash Legal Claims?: Hearing Before the H. Subcomm. on Commercial and Administrative Law of the H. Comm. on the Judiciary, 111th Cong. 148 (2009) (testimony of David Arkush stating that in success rates and award amounts, AAA arbitrations appear to be heavily slanted in favor of businesses); American Association for Justice, Searle Institute Report Shows Mandatory Arbitration Favors Corporations Over Consumers, AM. Ass'N FOR JUSTICE, http://www.justice.org/resources/searle_arbitration_rebut.pdf (last visited Oct. 27, 2009) ("While the authors try to paint a rosy picture of the mandatory arbitration process, the data actually illustrates otherwise"-citing the differing outcomes between business and consumer claimants).

12. Richard Lempert, A Classic at 25: Reflections on Galanter's 'Haves' Article and Work It Has Inspired, 33 LAW \& SOC’Y REV. 1099, 1110 (1999); see also MAINE BUREAU OF CONSUMER CREDIT PROTECTION, REPORT TO COMMITTEE: COMPILATION OF INFORMATION PROVIDED By CONSUMER ARBITRATION PROVIDERS 7 (Apr. 1, 2009) (“[A]lthough credit card banks or assignees prevail in most arbitrations, this fact alone does not necessarily indicate unfairness to consumers. The fact is that the primary alternative to arbitration (a civil action in court) also commonly results in judgment for the plaintiff.”), available at http://www.maine.gov/pfr/consumercredit/documents/ArbitrationProviders Report.rtf.

13. SeARle Civil Justice InST., supra note 9 , at 70.

14. Businesses tend to bring claims for amounts they are owed for goods provided and services 
Second, business claims are much more likely than consumer claims to be resolved on an ex parte basis-i.e., when the respondent fails to appear. ${ }^{15}$

Instead, the proper basis for comparison is to similar cases in court. Court adjudication is the default means of dispute resolution. Parties that agree to arbitrate contract out of that default. To evaluate arbitration meaningfully thus requires a comparison to the likely means by which the disputes otherwise would be resolved. Indeed, implicit, if not explicit, in legislative proposals to restrict the enforceability of pre-dispute arbitration clauses is that the disputes that previously would have been resolved in arbitration would instead be resolved in court.

In this article, we seek to undertake such a comparison. We compare debt collection cases brought by business claimants in arbitration- both individual AAA debt collection arbitrations and cases brought under a program of debt collection arbitrations administered by the AAA - to debt collection cases brought in court.

Our central findings are as follows:

- In the court cases studied, creditors won some relief as often, or more often, than in the arbitration cases studied (i.e., consumers prevailed more often in arbitration than in court). Creditors won some relief in 86.2 percent of the individual AAA debt collection arbitrations and 97.1 percent of the AAA debt collection program arbitrations that went to an award. By comparison, creditors won some relief in 98.4 percent to one-hundred percent of the debt collection cases in court that went to judgment. Even after controlling for differences among the types of cases and the venue in which they were brought using multivariate regression analysis, the likelihood of creditors winning in arbitration is less than in court, both for individual AAA debt collection arbitrations and for AAA debt collection program arbitrations.

- In the court cases studied, prevailing creditors were awarded as high a percentage, or a higher percentage, of what they sought than in the arbitration cases studied (i.e., consumers

already rendered. In such cases, the business faces fewer hurdles to establishing liability, and, when it does so, the amount it should be awarded is relatively easy to calculate and prove. Consumers tend to bring claims alleging delivery of defective goods or improper performance of services. Such cases tend to present more difficult questions of proving both liability and damages. Accordingly, consumers tend to win less often in cases that make it to an award, and, when they do win, tend to recover a lower percentage of the damages they seek.

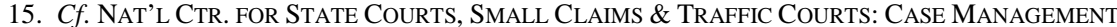
Procedures, Case Characteristics, and OUtCOMES IN 12 URban JuRISDiCTIONS 51-52 (1992) ("Differences in the winning percentages for business and individual plaintiffs are probably due to differences in the nature of the cases brought by businesses and individuals. Businesses bring primarily debt collection cases, a great majority of which are uncontested (disposed by default). Individuals usually bring consumer or tort cases, which are more likely to go to trial.”); see also infra Part III.D. 
fared better, or at least no worse, by this measure in arbitration than in court). Prevailing creditors were awarded 92.9 percent of the amount sought in the individual AAA debt collection arbitrations and 99.2 percent in the AAA debt collection program arbitrations we studied. By comparison, prevailing creditors were awarded from 96.2 percent to 99.5 percent of the amount sought in the debt collection cases in court that we studied. After controlling for differences among the cases using multivariate regression analysis, we found no statistically significant difference between creditor recovery rates in arbitration and in court.

- The rate at which debt collection cases were disposed of other than by award or judgment (e.g., by dismissal, withdrawal, or settlement) did not appear to differ systematically between arbitration and litigation. Just under half (44.8 percent) of the individual AAA debt collection arbitrations studied were disposed of other than by award, while 13.2 percent of the AAA debt collection program arbitrations studied were disposed of other than by award. By comparison, 22.1 percent to 35.0 percent of the debt collection cases in court that we studied were disposed of other than by judgment.

- $\quad$ The rate at which consumers responded (i.e., did not default) also did not appear to differ systematically between arbitration and litigation. In the individual AAA debt collection cases we studied, consumers responded in between 65.7 percent and 79.0 percent of the cases. In the AAA debt collection program arbitrations we studied, consumers responded in between 1.9 percent and 14.8 percent of the cases. By comparison, the consumer response rate in the court cases we studied ranged from 6.9 percent to 41.2 percent. ${ }^{16}$

These findings are subject to several important limitations. ${ }^{17}$ First, our findings on outcomes in arbitration are limited to debt collection arbitrations administered by the AAA. As have we indicated elsewhere,

16. As discussed infra Part III.D, the lower number in the range is the percentage of cases in which we have a high degree of confidence that the consumer responded, while the higher number is the percentage of cases in which the consumer might have responded.

17. This article focuses on claims brought by creditors against consumers. A similar comparison could be done for claims brought by consumers against businesses. Again, evaluating arbitration outcomes for consumer claimants requires a comparison to comparable cases brought by consumers in court. This comparison is more difficult than for creditor claims for at least two reasons. First, consumers appear to bring fewer cases against businesses than businesses bring against consumers. In our sample of Oklahoma cases seeking under $\$ 10,000$, consumer claimants brought two cases against businesses while business claimants brought 419 cases against consumers. In our sample of Oklahoma small claims cases, consumer claimants brought six cases against businesses while business claimants brought 330 cases against consumers. Second, the greater variation in types of claims brought by consumers against businesses makes identifying comparable cases more difficult. 
not all arbitrations are the same. We have not studied arbitrations administered by other providers, and do not assert that AAA debt collection arbitrations necessarily are representative of all other consumer arbitrations. Relatedly, the number of individual debt collection arbitrations administered by the AAA during the sample period is small relative to the number of debt collection cases in court and the number of cases administered by the AAA under a single debt collection arbitration program. Thus, caution must be used in drawing conclusions from the comparison.

Second, the sample of court cases is not from a nationwide sample, but rather is limited by data availability to cases from Oklahoma and Virginia state courts, and student loan cases in federal court. The results are broadly consistent with each other, and with prior studies of small claims and other courts. ${ }^{18}$ But results may differ in different courts.

Third, the cases in court and in arbitration that we studied likely are not fully comparable. We have focused on debt collection cases to enhance comparability, and have sought to control for important differences among the cases (such as amount sought, type of claimant, and venue in which the case was brought) through multiple regression analysis. But differences no doubt remain. Indeed, the fact that some of the cases are resolved in

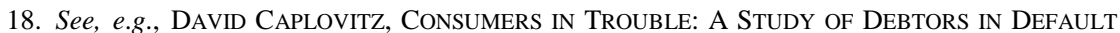
221 (1974) (finding more than 90\% of debt collection actions in Chicago, Detroit, and New York resolved by default judgment); NAT'L CTR. FOR STATE COURTS, supra note 15, at 51 (finding default judgments in favor of business claimants in from 93\%-100\% of cases in cities studied, with exception of Seattle, which had a default judgment rate of 80\%); Marc Galanter, Contract in Court: Or Almost Everything You May or May not Want to Know About Contract Litigation, 2001 WIS. L. REV. 577, 600 (using data on federal diversity actions, excluding personal injury cases, from 1986-94; finding that corporate plaintiffs "won $90 \%$ of the cases in which they sued individuals and lost only $50 \%$ of the cases in which individuals sued them”); Suzanne E. Elwell \& Christopher D. Carlson, The Iowa Small Claims Court: An Empirical Analysis, 75 IowA L. REV. 433, 508 (1990) (using random sample of small claims cases from Polk and Johnson Counties and all small claims cases from Keokuk county; finding that when businesses sued individuals, businesses won $84 \%$ of the cases by default judgment and $14 \%$ of the cases at trial; individual won 2\% of the cases at trial); Hillard M. Sterline \& Philip G. Schrag, Default Judgments Against Consumers: Has the System Failed?, 67 DENV. U.L. REV. 357, 361 (1990) (using random sample of cases from D.C. Small Claims Court in 1988; reporting: "Two hundred eightyseven files of suits against consumers were selected. Two hundred thirteen of them (74\%) had resulted in default judgments. In another sixty-three cases (22\%), the defendant had appeared in court but consented to pay everything asked for by the plaintiff. In eleven cases (4\%), the plaintiff had voluntarily dismissed the case. Of the 287 files sampled, none had resulted in a trial.”); Barbara Yngvesson \& Patricia Hennessey, Small Claims, Complex Disputes: A Review of the Small Claims Literature, 9 LAW \& SOC’Y REV. 219, 244-45 (1975) (finding plaintiff win rates ranging from 85\% to 100\%); Urban Justice Ctr., DeBt WeIGHT: The CONSUMER CREDIT CRISIS IN NEW YORK CiTY AND ITS IMPACT ON THE WORKING POOR 17-18 (Oct. 2007) (using random sample of 600 consumer debt cases filed in New York City Civil Court in February 2006; reporting: "In 81.8\% of the cases reviewed in our study, the court entered a default judgment against the defendant. . . . A much smaller percentage of cases, $5.9 \%$, were settled by both parties. . . 3.2\% of the cases were unilaterally discontinued by the plaintiff and $4.5 \%$ were filed but never served on the defendant. In others [apparently 6\%], the case appeared to be still pending. Not a single case went to trial or was otherwise adjudicated on the merits.”), available at http://www.urbanjustice.org/pdf/publications/CDP_Debt_Weight.pdf. 
arbitration and some are resolved in court-and that the differing adjudication is not random but determined by the parties-itself is a difference that introduces possible selection bias into the sample. Moreover, to the extent we study judgments and awards, differential rates of settlement among the venues also might bias our results.

Because of these limitations, we cannot determine definitively how outcomes for cases brought by creditors in arbitration compare to outcomes for cases brought by creditors in court. That said, we can say that nothing in our study provides any evidence of biased outcomes in arbitration. The outcomes we observe appear to be the result of the type of case being adjudicated rather than differences between arbitration and litigation. Moreover, the study does definitively demonstrate that win rates in arbitration alone do not show that arbitration is biased. The win rates for creditors in claims they brought in court are as high as or higher than the win rates for claims brought by creditors in arbitration.

Part II describes the data sources used in this article. Part III presents our empirical results, comparing creditor win rates and recoveries and consumer response rates in debt collection cases in arbitration to debt collection cases in court. Part IV sets out the results of our initial regression analysis, controlling for important differences among the cases. Finally, Part V concludes by summarizing our findings and discussing the implications of this article for the broader debate over consumer arbitration.

\section{DATA SOURCES}

This part describes the data sources on which we rely in this article. The arbitration cases we examine are consumer arbitrations administered by the American Arbitration Association, including both individual debt collection claims brought by creditors against consumers and claims brought by a single debt buyer as part of a consumer debt collection program administered by the AAA. The court cases we examine are cases involving unpaid student loans in federal court and a more general sample of debt collection cases from Oklahoma and Virginia state courts.

All of the cases in the sample, both in arbitration and in court, involve attempts by creditors to collect unpaid debts from consumers. As such, at a fundamental level the cases are similar. Moreover, debt collection cases tend to present relatively simple legal issues-was the debt incurred and did the consumer pay? At that level, too, the cases are similar. That said, the cases differ in various respects, most notably as to the type of creditor and the amount sought. These characteristics of the cases are described in more detail in the following sections. 


\section{A. INDIVIDUAL AAA DEBT COLLECTION ARBITRATIONS}

The individual AAA debt collection arbitrations we studied are debt collection cases filed by a variety of creditors against individual consumers and administered by the AAA as part of its consumer arbitration caseload (as distinguished from the debt collection program arbitrations described in the next section). They consist of both awarded cases and non-awarded cases. The awarded cases are included in the 301 AAA consumer arbitrations closed by an award between April and December $2007^{19}$ (the "AAA case file sample"), which are described in our Preliminary Report issued in March 2009. ${ }^{20}$ Just over twenty percent (61 of 301, or 20.3 percent) of the cases in the AAA case file sample involved claims brought by businesses against consumers, typically as creditors seeking to recover amounts allegedly owed by consumers for services rendered or goods supplied. To enhance comparability with the court cases we studied, we excluded from the sample three cases brought by business claimants that likely should not be classified as debt collection cases. ${ }^{21}$

The non-awarded cases are included in an additional 406 cases that were closed during the same period other than by an award, either administratively, by settlement, or by the claimant's withdrawal of its claim. Of those cases, 47 appear to be brought by business claimants. Because of AAA policies on the retention of original case files, we were not able to review the files for the non-awarded cases. As a result, we rely on the AAA's coding of outcomes in those cases, although acknowledging uncertainty as to its reliability. ${ }^{22}$ Overall, then, the individual AAA consumer arbitrations in our sample consist of 58 awarded cases and 47 non-awarded cases, for a total of 105 cases.

The most common types of creditors in the sample were home builders (24.8 percent), law and accounting firms (23.8 percent), consumer finance companies (including credit card issuers) (15.2 percent), and real estate brokers (13.3 percent). The average amount sought by the creditors in the cases in the sample was $\$ 20,445.47 .{ }^{23}$

19. The focus on cases closed by an award during this time period was based on the availability of the original case files. See SEARLE CiviL Justice InST., supra note 9, at 37.

20. For more information on the AAA case file sample, see $i d$. at 37-38.

21. Two of the cases involved disputes over payment of insurance payouts, and one case involved a request by a business to remedy defective goods.

22. SEARLE Civil JUSTICE InST., supra note 9, at 52.

23. For awarded cases, the average amount sought (which we were able to verify from the AAA's files) in individual AAA debt collection arbitrations was \$22,136.55; for non-awarded cases, the average amount sought (which we were not able to verify from the AAA's files) was $\$ 18,313.23$. The overall average is what is reported in the text. 


\section{B. AAA Debt Collection PROGRAm ARbitrations}

Beginning in September 2007, the AAA began administering a program of debt collection arbitrations filed by a single buyer of consumer debt. $^{24}$ We refer to these cases as "AAA debt collection program arbitrations" to distinguish them from the individual consumer arbitrations filed by creditors seeking to recover amounts allegedly owed by consumers, described in the previous section.

The first awards under the program were issued in March 2008, and over 80 percent of the total awards under the program were issued between September 2008 and February 2009. ${ }^{25}$ While the program was ongoing, arbitrators issued a total of 16,500 awards. In these awarded cases, the creditor sought an average of $\$ 1172.20 .^{26}$ Another 2,785 cases, including all cases withdrawn prior to March 18, 2009, were resolved in other ways. ${ }^{27}$ The creditor withdrew all 27,839 remaining claims between mid-March 2009 and June 2009, so that by June 2009, the creditor had withdrawn all remaining cases it had filed under the program. At the time the AAA adopted its debt collection arbitration moratorium, it was no longer administering any cases under the program.

Subject to a confidentiality agreement, the AAA made its electronic database of debt collection program arbitration data available to us. The database recorded whether a case was resolved by an award, withdrawn, or closed administratively; whether the consumer respondent participated in the case; whether the creditor won some relief in the case; and the percentage of the amount sought by the prevailing creditor that it was awarded. Because the arbitrators filled out an electronic template in making their awards, ${ }^{28}$ the award data in the database were directly entered by the arbitrators through the template. We then verified the data in a

24. All the claims in the AAA's debt collection program arbitrations were for amounts owed on wireless phone customer accounts, which had been purchased by a third party debt buyer. The claims were generally two or more years old and had already been through the original wireless company's own collection process. For further description of the AAA debt collection program arbitrations, see Appendix A. For an early report on outcomes under the program, based on data disclosed by the AAA, see Federal Arbitration Act, supra note 11, at 8.

25. The Searle Civil Justice Institute Preliminary Report, supra note 9, did not deal with these awards because they were issued after the time period covered by that report; data collection for the Preliminary Report was complete before the bulk of awards under the debt collection program were issued.

26. Unlike many of the other debt collection claims we studied, the creditor in the AAA debt collection program arbitrations sought to recover only the past due amounts billed but not interest on those amounts. Due to the AAA's data collection process, only awarded cases contained information on the amount claimed without including costs. As such, we could not accurately calculate the average amount sought in cases that were not resolved by an award.

27. The cases resolved in other ways include cases that were withdrawn, cases that were closed administratively, and cases that were rejected for lack of notice to the consumer (which often were in the form of an award).

28. See app. A. 
sample of 408 cases by examining the original electronic case files, and corrected the data as described in Appendix B.

\section{Federal Student LoAn Collection CASes}

Data compiled by the Administrative Office of the U.S. Courts (AO) are widely used by researchers studying outcomes in federal court cases. ${ }^{29}$ Few debt collection cases, however, are brought in federal court. ${ }^{30}$ One exception is cases brought by or on behalf of the U.S. government to collect unpaid student loans. Because the federal government is the plaintiff in such cases, it can file suit in federal court despite the relatively low amounts sought (i.e., amounts well below the amount in controversy required for diversity cases).$^{31}$

We examined the AO data on all federal civil cases terminated between late 2006 and late 2007 (the most recent period for which data were available at the time of the study) coded as involving unpaid student loans. ${ }^{32}$ Our sample consists of those cases in which a prevailing party is recorded in the dataset and for which the amount demanded ${ }^{33}$ was recorded as a non-zero amount. ${ }^{34}$ To correct obvious coding errors in the data, we examined federal court docket sheets available on Westlaw, and, when necessary, the electronic court files using PACER. ${ }^{35}$ Because we limited the sample to cases in which one party or the other was coded as prevailing, we excluded cases that were settled, dismissed, or otherwise withdrawn before a final judgment was entered.

The resulting sample consists of 382 cases in which the federal government sought to recover unpaid student loan amounts from a consumer. The time period covered (between late 2006 and late 2007) is similar to the time period for the individual AAA consumer arbitrations

29. For a list of studies, see, e.g., Inter-University Consortium for Political and Social Research, Citation Search Results for 8429, http://www.icpsr.umich.edu/icpsrweb/ICPSR/biblio/studies/8429/ resources (last visited Oct. 27, 2009).

30. See, e.g., Federal Trade Comm'n, Collecting Consumer Debts: The Challenges of CHANGE 55 (Feb. 2009), http://www.ftc.gov/bcp/workshops/debtcollection/dcwr.pdf.

31. 28 U.S.C. $§ 1345$ (2010) (no amount in controversy requirement for cases in which the United States is plaintiff).

32. Fed. Judicial Ctr., Federal Court CASEs: InTEgrated Database, 2007 (DS1: Civil Terminations Data, 2007) (ICPSR Study No. 22300) (last updated June 23, 2009), available at http://www.icpsr.umich.edu/cocoon/NACJD/STUDY/22300.xml ("nature of suit” variable coded as 152).

33. See Theodore Eisenberg \& Margo Schlanger, The Reliability of the Administrative Office of the U.S. Courts Database: An Initial Empirical Analysis, 78 NoTRE DAME L. REV. 1455, 1461 n.33 (2003) (identifying limitations on "amount demanded" variable). Those limitations are less troubling here because of the nature of the claim: a liquidated amount owed for failure to pay back a student loan. We verified the amounts demanded against the original complaint when there was a reason to question the amount as coded.

34. We limited the sample to these cases so that we could calculate win rates and the percent of the amount claimed recovered by the creditor using the data in the dataset.

35. See appendix $\mathrm{C}$ for further discussion of errors in the Federal Court/AO dataset. 
studied. The amount sought by the government (i.e., the creditor) in the cases in the sample averaged $\$ 17,185.86$ - similar to the amount sought in the individual AAA debt collection arbitrations but much larger than the amount sought in the AAA debt collection program arbitrations. One respect in which student loan collection actions brought by the federal government differ from other debt collection actions is that there is no statute of limitations for recovery of unpaid student loans, so that no statute of limitations defense is available to the consumer. ${ }^{36}$

\section{State Court DebT Collection CASES}

As already indicated, most debt collection cases are brought in state court, rather than federal court. ${ }^{37}$ But systematic data from state courts are much less available. ${ }^{38}$ In this article, we present data on debt collection cases from Oklahoma and Virginia state courts. We studied those two states solely for reasons of data availability: Oklahoma provides good online access to case dockets, while we were able to obtain a preexisting dataset of debt collection cases brought in Virginia state courts.

\section{Oklahoma State Court Cases}

The Oklahoma state court cases consist of a sample of cases closed between March 31, 2007, and January 1, 2008 (the same time period used for our original study of AAA consumer arbitrations). We used Oklahoma as the source of the data because of the ready availability of docket sheets and court filings online. Unlike the web pages of other state court systems, the Oklahoma court web page permits searches by classes of cases and dates of filing, facilitating the collection of a sample of cases. Not all Oklahoma counties make court dockets available online, and, of those that do, not all provide access to all filings in the cases. We limited our data collection to those counties that make all filings available online. ${ }^{39}$

The Oklahoma district courts are divided into three divisions for civil claims: claims seeking more than $\$ 10,000$, claims seeking less than

36. 20 U.S.C. $§ 1091 \mathrm{~A}(\mathrm{a})$ (2006). We appreciate Paul Bland pointing out this difference in his oral testimony at a hearing of the Domestic Policy Subcommittee of the House Oversight Committee. See Arbitration or Arbitrary, supra note 7 (statement of Paul Bland).

37. See supra text accompanying note 30 .

38. The most commonly used dataset on state court cases is the Civil Justice Survey of State Trials. See generally Civil Justice Survey of State Trials, NaT'L ARChives of CRIMINAl Justice DATA, http://www.icpsr.umich.edu/cocoon/NACJD/SERIES/00071.xml (last visited October 4, 2010). But because so few debt collection cases go to trial, that dataset is of little use to us.

39. Those counties are rural and mixed rural-urban counties: Adair County, Canadian County, Cleveland County, Garfield County, Logan County, Payne County, and Pushmataha County. Oklahoma County, the county in which Oklahoma City is located, provides online access to court filings, but does not include the complaint among the documents available online. Tulsa County, where Tulsa is located, has docket sheets available online, but does not provide online access to court filings. 
$\$ 10,000$, and small claims. $^{40}$ Because most AAA debt collection arbitrations involved relatively small stakes, ${ }^{41}$ we focused on the latter two classes of cases. We selected a random sample of 500 cases from each of the divisions, and excluded cases that were not debt collection cases (most commonly, eviction actions) and cases between two businesses or two individuals.

The resulting sample consists of 421 cases seeking less than $\$ 10,000$ and 336 small claims cases filed in Oklahoma district courts from rural and mixed rural-urban counties. Of the 421 cases filed in the under $\$ 10,000$ division, 419 were brought by creditors seeking to recover unpaid debts; only two were brought by consumers against businesses. The average amount sought was $\$ 4,750.28$. The majority of the creditor claims (245 of 419 , or 58.5 percent) were brought by a party other than the original creditor, either a debt collection agency or debt buyer. This is not surprising, because Oklahoma law precludes such parties from suing in small claims court. ${ }^{42}$ Of the 336 cases filed in the small claims division, 330 were brought by creditors seeking to recover unpaid debts; only six were brought by consumers against businesses. The average amount sought was $\$ 1,284.78$.

\section{Virginia State Court Warrant in Debt Cases}

The Virginia cases are a statewide random sample of cases from 2005 collected by Professor Richard Hynes for a research project on debt collection lawsuits in Virginia. ${ }^{43}$ We limited the sample to warrant in debt cases ${ }^{44}$ brought by consumer finance companies, medical service providers, law firms, and other businesses against consumers. ${ }^{45}$ We verified the data against online case information available from the Virginia court system. The information available online did not include the actual case filings, but

40. OKLA. Stat. AnN. tit. $20 \S 91.2$ (West 2010); Okla. Sup. Ct. Admin. Directive 99-87 (Dec. 16, 1999), reprinted in Supreme Court Administration Directive - Uniform System of Designating and Numbering Cases, 70 OKLA. B.J. 3875 (1999). Small claims are those seeking less than \$6,000. OKLA. STAT. ANN. tit. 12 § 1751(A) (West 2010).

41. The average amount sought in the awarded AAA debt collection program cases was $\$ 11,72.20$. Almost 95\% (55 of 58) of the individual AAA debt collection arbitrations sought less than $\$ 75,000$, and about 34\% (20 of 58) sought less than $\$ 10,000$.

42. OKLA. STAT. ANN. tit. $12 \S 1751$ (B) (West 2010) ("No action may be brought under the small claims procedure by any collection agency, collection agent, or assignee of a claim ....”). We have not collected data on cases filed in the over $\$ 10,000$ division of the Oklahoma district courts.

43. Richard M. Hynes, Broke But Not Bankrupt: Consumer Debt Collection in State Courts, 60 FLA. L. Rev. 1, 46 (2008). We very much appreciate Professor Hynes' willingness to make his data available to us.

44. Warrant in debt cases are claims seeking recovery of money, which would include tort cases, for example, as well as debt collection cases. But it seems unlikely that many claims by businesses against consumers would involve tort claims. See id.

45. To enhance the comparability of the claims to our individual AAA consumer arbitrations, we excluded claims brought by governments (not including public universities) and landlords. 
rather a summary information sheet. We verified the coding received from Professor Hynes against the summary information sheet, but were not able to verify the coding against the actual case filings.

The sample consists of 283 cases brought by businesses against consumers. While the dataset includes data on the amounts awarded to the prevailing party, it does not include data on amounts sought by plaintiffs. ${ }^{46}$

\section{EMPIRICAL RESULTS}

This part reports the findings from our study of debt collection cases in arbitration and in court. It addresses four issues: (1) the extent to which creditors win some relief (creditor win rates) in arbitration and in litigation; (2) the extent to which prevailing creditors are awarded the amounts they claim (creditor recovery rates) in arbitration and litigation; (3) the extent to which cases are disposed of other than by an award in debt collection arbitration or other than by a judgment in debt collection litigation (rate of other case dispositions); and (4) the extent to which consumers respond to claims (consumer response rates) in arbitration and litigation. ${ }^{47}$ Our findings are subject to several limitations, described in more detail above. ${ }^{48}$ First, the arbitration findings are limited to debt collection arbitrations administered by the AAA and are not necessarily representative of all arbitrations. Second, the court findings are not based on a national sample of cases and may differ in other court systems. Third, cases adjudicated in arbitration and litigation necessarily are different in respects that make comparisons difficult.

\section{A. Creditor Win Rate}

As explained above, ${ }^{49}$ the win rate of creditors in arbitration, either alone or when compared to the win rate of consumer claimants in arbitration, does not itself provide a meaningful evaluation of outcomes in arbitration. Instead, to evaluate outcomes in arbitration, creditor win rates in arbitration must be compared to creditor win rates for comparable cases in court. This section seeks to undertake such a comparison.

46. Given that creditors ordinarily are awarded a high percentage of the amount sought in debt collection cases, the average amount awarded provides some information on the amount sought by creditors. In the Virginia cases, prevailing creditors were awarded an average of $\$ 2,144.14$ per case (based on 185 cases with prevailing creditors).

47. See app. D (providing a breakdown of the results underlying these finding by venue). Note that in all the calculations in this part, we excluded cases in which notice was not given or process was not served. For tests of statistical significance after controlling for relevant factors, see the regression results infra Part IV.

48. See supra text accompanying notes $17-18$.

49. See supra text accompanying notes 12-15. 
Table 1 summarizes win rates of creditors in individual AAA debt collection arbitrations, AAA debt collection program arbitrations, federal court student loan collection cases, and state court cases from Oklahoma and Virginia. A case was treated as a win when the creditor was awarded some amount from the consumer, other than court or arbitration costs. ${ }^{50}$ The win rate is measured as a percentage of total judgments or awards, consistent with how we defined win rate in prior research. ${ }^{51}$

As shown in Table 1, the cases with the lowest creditor win ratesthat is, the cases in which consumers fared the best-were the AAA debt collection arbitrations. In the individual AAA debt collection arbitrations, creditors won some relief in 86.2 percent of awarded cases, ${ }^{52}$ while in the AAA debt collection program arbitrations, creditors won some relief in 97.1 percent of the awarded cases. By comparison, creditors won some relief in 98.4 percent of the Virginia state court cases, in 99.7 percent of the federal student loan collection cases, in 99.3 percent of the Oklahoma debt collection cases under $\$ 10,000,{ }^{53}$ and in one-hundred percent of the Oklahoma small claims cases going to judgment.

50. See SEARLE CIVIL JUSTICE INST., supra note 9, at 67 .

51. Id.

52. The Searle Civil Justice Institute Preliminary Report focused on claims brought by businesses, rather than simply debt collection claims, and found that business claimants won some relief in $83.6 \%$ of the cases they brought. See id. at 67-68. Of the business claims studied, however, three cases likely should not be classified as debt collection cases. See supra text accompanying note 21. The consumer prevailed in two of the three cases. With those cases excluded, the business won some relief in 50 of 58 (or $86.2 \%$ ) of the cases in the sample. Another eleven cases involved claims by a business to keep a deposit paid by the consumer. Those cases differ from more traditional debt collection cases in that the business already has possession of the money it is seeking to recover. But they are similar in that the business is asserting a claim for money alleged to be owed by a consumer. Accordingly, in our view it is appropriate to treat such claims as debt collection claims for purposes of this analysis. If those claims are excluded, businesses prevailed in 41 of the 47 cases (or 87.2\%) that clearly were debt collection cases in the sample.

53. The win rate $(99.3 \%)$ reported here differs marginally from preliminary results reported in testimony before the House Oversight Committee. See Arbitration or Arbitrary, supra note 7 (testimony of Christopher R. Drahozal reporting win rate of 99.7\%). The win rate previously reported did not consider dismissals; here, we classify as a consumer win one case in which the court vacated a default judgment in favor of the creditor and dismissed the case against a consumer. This change reduces the creditor win rate from $99.7 \%$ to $99.3 \%$. 
Table 1: Creditor Win Rates in Arbitration Court, Claims Brought by Creditors

\begin{tabular}{|r|ccc|}
\hline Venue & $\begin{array}{c}\text { Creditor } \\
\text { Claimant Wins }\end{array}$ & $\begin{array}{c}\text { Total Awards or } \\
\text { Judgments }\end{array}$ & $\begin{array}{c}\text { Creditor } \\
\text { Claimant Win } \\
\text { Rate }\end{array}$ \\
\hline Individual AAA Debt Collection Arbitrations & 50 & 58 & $\mathbf{8 6 . 2 \%}$ \\
AAA Debt Collection Program Arbitrations & 16,019 & 16,500 & $\mathbf{9 7 . 1 \%}$ \\
Federal Court Student Loan Collection Cases & 297 & 298 & $\mathbf{9 9 . 7 \%}$ \\
Oklahoma State Court Cases, Claims $<\$ 10,000$ & 290 & 292 & $\mathbf{9 9 . 3 \%}$ \\
Oklahoma State Court Cases, Small Claims & 191 & 191 & $\mathbf{1 0 0 . 0 \%}$ \\
Virginia State Court Cases & 185 & 188 & $\mathbf{9 8 . 4 \%}$ \\
\hline
\end{tabular}

The results in Table 1 include adjudications both in contested cases (e.g., cases resolved on summary judgment or after a hearing) as well as in uncontested cases (e.g., default judgments and ex parte arbitration awards). Most of the judgments in debt collection cases in court, and many awards in debt collection arbitrations, are entered in uncontested cases. ${ }^{54}$ Because the creditor almost always wins in the uncontested cases in our sample, those cases may not be the best types of cases to use in evaluating whether arbitration is biased in favor of creditors.

Accordingly, Table 2 summarizes win rates in contested debt collection cases in AAA arbitration and in court. Because of the frequency of default judgments and ex parte awards in debt collection cases, the number of contested cases is only a small fraction of the total number of judgments and awards in the sample, so that the sample sizes for the percentages in Table 2 are much smaller than those in Table 1. Again, the cases with the lowest creditor win rates - that is, the cases in which the consumers fared the best-were the AAA debt collection arbitrations. In contested cases in which arbitrators ruled on the merits, creditors won some relief in 77.8 percent of the individual AAA debt collection arbitrations and either 64.1 percent or 85.2 percent of the AAA debt collection program arbitrations. The lower creditor win rate for AAA debt collection program arbitrations (64.1 percent) is derived from the cases in which we could verify in the electronic record that the consumer had in fact participated in the case. The higher creditor win rate for AAA debt collection program arbitrations (85.2 percent) is derived from all cases identified by the arbitrator as cases in which the consumer participated, even if we could not verify the fact of consumer participation from the file. Even the higher creditor win rate is in line with creditor win rates in contested court cases, which range from a low of 80.0 percent in Oklahoma cases under $\$ 10,000$ to a high of one-hundred percent in Oklahoma small claims cases. 
Table 2: Creditor Win Rates in Contested Cases in Arbitration and in Court, Claims Brought by Creditors

\begin{tabular}{|r|ccc|}
\hline Venue & $\begin{array}{c}\text { Creditor } \\
\text { Claimant Wins } \\
\text { in Contested } \\
\text { Cases }\end{array}$ & $\begin{array}{c}\text { Total Awards } \\
\text { or Judgments } \\
\text { in Contested } \\
\text { Cases }\end{array}$ & $\begin{array}{c}\text { Creditor } \\
\text { Claimant Win } \\
\text { Rate in } \\
\text { Contested Cases }\end{array}$ \\
\hline Individual AAA Debt Collection Arbitrations & 28 & 36 & $\mathbf{7 7 . 8 \%}$ \\
AAA Debt Collection Program Arbitrations & $41-305$ & $64-358$ & $\mathbf{6 4 . 1 \% - 8 5 . 2 \%}$ \\
Federal Court Student Loan Collection Cases & 11 & 12 & $\mathbf{9 1 . 7 \%}$ \\
Oklahoma State Court Cases, Claims $<\$ 10,000$ & 8 & 10 & $\mathbf{8 0 . 0} \%$ \\
Oklahoma State Court Cases, Small Claims & 18 & 18 & $\mathbf{1 0 0 . 0} \%$ \\
Virginia State Court Cases & 15 & 18 & $\mathbf{8 3 . 3} \%$ \\
\hline
\end{tabular}

\section{B. CREDITOR RECOVERY RATE}

Win rates, of course, provide only a partial picture of outcomes in arbitration and in court. The standard measure of win rates, which we also use, treats all cases in which the prevailing party is awarded some relief as a win for that party, regardless of whether the party is awarded all or only a small part of the relief to which it is legally entitled. ${ }^{55}$ To examine possible variations in the degree of creditor success, this section looks at creditor recovery rates-i.e., the percentage of what the creditor was seeking that it was awarded.

Table 3 sets out one measure of creditor recovery rate: the percentage of cases in which a prevailing creditor was awarded one-hundred percent (or more) of the amount it sought. ${ }^{56}$ Table 4 sets out a related measure of creditor success: the average percentage of the amount sought that was awarded to a prevailing creditor. ${ }^{57}$ The pattern shown in both tables is almost identical. Prevailing creditors recover the lowest percentage of what they are seeking in individual AAA consumer arbitrations, while they recover the highest percentage of what they are seeking in Oklahoma state court cases under $\$ 10,000$. The recovery rate of creditors in AAA debt collection program arbitrations is similar to the recovery rate in debt collection cases in court, with the exception of Oklahoma small claims cases, in which the recovery rate is lower.

55. The issue more commonly arises in calculating consumer wins in arbitration, when use of the win rate to measure consumer success may overstate how well consumers fare. E.g., Peter B. Rutledge, Whither Arbitration?, 6 GEO. J.L. PuB. POL'y 549, 557 (2008). When the creditor is the claimant, a high win rate similarly may overstate the degree of creditor success (or understate how well consumers fare) in a particular venue.

56. For the Virginia warrant in debt cases, we do not have data on the amount sought by the plaintiff because that data is not available in the Virginia courts online database. Accordingly, those cases are not included in the results reported in this section.

57. Consistent with the Preliminary Report, we calculated the percent recovery for creditors as the amount of damages awarded divided by the amount of damages sought. SEARLE Civil JUSTICE INST., supra note 9 , at 69 . 
Table 3: Percentage of Cases in which Creditor Was Awarded $100 \%$ of Amount Sought, Claims Brought by Creditors

\begin{tabular}{|r|ccc|}
\hline Venue & $\begin{array}{c}\text { Creditor } \\
\text { Claimant Was } \\
\text { Awarded 100\% } \\
\text { of Claim }\end{array}$ & $\begin{array}{c}\text { Creditor Wins } \\
\text { with Award } \\
\text { Amounts }\end{array}$ & $\begin{array}{c}\text { \% of Time } \\
\text { Creditor Was } \\
\text { Awarded 100\% } \\
\text { of Claim }\end{array}$ \\
\hline Individual AAA Debt Collection Arbitrations & 35 & 50 & $\mathbf{7 0 . 0} \%$ \\
AAA Debt Collection Program Arbitrations & 15,604 & 16,019 & $\mathbf{9 7 . 4 \%}$ \\
Federal Court Student Loan Collection Cases* & 285 & 295 & $\mathbf{9 6 . 6 \%}$ \\
Oklahoma State Court Cases, Claims $<$ \$10,000** & 284 & 288 & $\mathbf{9 8 . 6 \%}$ \\
Oklahoma State Court Cases, Small Claims & 167 & 191 & $\mathbf{8 7 . 4 \%}$ \\
Virginia State Court Cases & N/A & N/A & N/A \\
\hline
\end{tabular}

*Data on the amount awarded were missing in two of the cases. In a number of the cases, the damages awarded were more than the amount claimed, almost always because interest continued to accrue while the case was pending. In those cases, the creditor was awarded the full amount of principal sought, and so accordingly we capped the recovery at $100 \%$ of the amount claimed.

**Data on the amount awarded were missing in two of the cases. In the four cases in which the creditor was awarded less than $100 \%$ of the amount sought, the percent ranged from $30 \%$ to $97 \%$. In the case in which the creditor was awarded thirty percent of the amount sought, the creditor sought to recover the collateral for the loan as well. The difference between the amount sought and the amount awarded may reflect the value of the collateral.

Table 4: Average Percent of Amount Claimed Awarded to Creditor, Claims Brought by Creditors*

\begin{tabular}{|r|cc|}
\hline Venue & $\begin{array}{c}\text { Creditor Claimant } \\
\text { Wins with Award } \\
\text { Amounts }\end{array}$ & $\begin{array}{c}\text { Average Percent } \\
\text { Recovery for } \\
\text { Creditor Claimants }\end{array}$ \\
\hline Individual AAA Debt Collection Arbitrations & 50 & $\mathbf{9 2 . 9 \%}$ \\
AAA Debt Collection Program Arbitrations & 16,019 & $\mathbf{9 9 . 2 \%}$ \\
Federal Court Student Loan Collection Cases & 295 & $\mathbf{9 9 . 3 \%}$ \\
Oklahoma State Court Cases, Claims $<\$ 10,000$ & 288 & $\mathbf{9 9 . 5 \%}$ \\
Oklahoma State Court Cases, Small Claims & 191 & $\mathbf{9 6 . 2 \%}$ \\
Virginia State Court Cases & N/A & N/A \\
\hline
\end{tabular}

*Again, we capped the recovery percentage at $100.0 \%$.

**The percent recovery here (92.9\%) differs from the percent recovery in the Preliminary Report (93.0\%), see Searle Civil Justice Institute, supra note 9, at 69, because of the exclusion of one case in which the creditor prevailed that likely was not a debt collection case. In that case, the creditor was awarded $100.0 \%$ of the amount sought.

\section{RATE OF OTHER CASE DisPositions}

The measures of win rates discussed above focus on cases in which the court entered a judgment or the arbitrator made an award, consistent with the definition of a win in our Preliminary Report. ${ }^{58}$ Such a measure does not, however, take into account other possible case dispositions such as settlements or dismissals that do not necessarily result in entry of judgment or making of an award. ${ }^{59}$

58. SEARLE Civil JUSTICE InST., supra note 9, at 67.

59. A settlement may be turned into a judgment (an "agreed judgment" or a "consent judgment") or an award (an "award on agreed terms"). The tables in Appendix D identify the numbers of such settlements. We did not include them in the win rates described in Parts III.A and III.B because they were not adjudications by the court or the arbitrator. In most cases the settlement awarded the creditor 
To provide some sense of how other case dispositions compare in court and in arbitration, Table 5 summarizes the percentage of cases that go to an award (in arbitration) or a judgment (in court) as a percentage of the total cases in which notice was given to the consumer respondent (by service of process or otherwise). ${ }^{60}$ The individual AAA debt collection arbitrations had the highest rate of other case dispositions (44.8 percent), while the AAA debt collection program arbitrations had the lowest rate (13.2 percent). The court cases we studied were in between, ranging from 22.1 percent to 35.0 percent.

Table 5: Other Case Dispositions as a Percent of Total Cases (with Notice), Claims Brought by Creditors
\begin{tabular}{|r|ccc|}
\hline Venue & $\begin{array}{c}\text { Other Case } \\
\text { Dispositions in } \\
\text { Cases with Notice }\end{array}$ & $\begin{array}{c}\text { Total Cases } \\
\text { with Notice }\end{array}$ & $\begin{array}{c}\text { \% of Other Case } \\
\text { Dispositions }\end{array}$ \\
\hline Individual AAA Debt Collection Arbitrations & 47 & 105 & $\mathbf{4 4 . 8 \%}$ \\
AAA Debt Collection Program Arbitrations & 2,516 & 19,016 & $\mathbf{1 3 . 2 \%}$ \\
Federal Court Student Loan Collection Cases & N/A & N/A & N/A \\
Oklahoma State Court Cases, Claims < \$10,000 & 83 & 375 & $\mathbf{2 2 . 1 \%}$ \\
Oklahoma State Court Cases, Small Claims & 103 & 294 & $\mathbf{3 5 . 0} \%$ \\
Virginia State Court Cases & 73 & 261 & $\mathbf{2 8 . 0 \%}$ \\
\hline
\end{tabular}

Unfortunately, it is not possible to distinguish reliably between settlements and dismissals for most of the samples we studied. The AAA identified a number of settled cases among the individual AAA debt collection arbitrations, but did so by relying on self-reporting by the parties, which may not be accurate. ${ }^{61}$ Withdrawals by the creditor in the AAA debt collection program arbitrations may be due to settlements, although that seems unlikely. ${ }^{62}$ Regardless, we have no way of determining whether that is so. Further, dismissals in court typically are sought by the creditor, but we have no way to verify whether they are due to settlement or some other reason. Thus, we are unable to draw any firm conclusions about the nature of the other dispositions and how they might be relevant to how consumers fare in debt collection cases. That said, based on the available data, there is no obvious pattern suggesting that cases in arbitration differ systematically from cases in court in this regard.

If we were able to characterize the nature of the other dispositions more precisely, it might have some effect on our win rate estimates. Some dismissals might be adjudications in favor of the consumer; indeed, we classify two cases as consumer wins in which the court vacated a default

the full amount sought, although usually subject to a payment schedule to be followed by the consumer.

60. Because of the way we used and verified the federal courts/AO data, we do not have results to report for student loan collection cases. See supra text accompanying notes 33-34.

61. Of the total other case dispositions among the individual AAA debt collection arbitrations, 33 of 47 (70.21\%) were coded by the AAA as having settled.

62. Given the overall low level of consumer participation in these cases. See supra Part III.D. 
judgment in favor of the creditor and dismissed the claim against the consumer. But not all dismissals, even ones that do not result from settlements, are necessarily adjudications in the consumer's favor. ${ }^{63}$ Moreover, it may well be that many, if not most, of the dismissals are due to settlements. If so, the varying rates of other case dispositions will not have a significant effect on the win rates discussed above. ${ }^{64}$

One possible explanation for the varying rates of other case dispositions is that they may be related to the frequency with which a consumer fails to respond in the case. When consumers fail to respond, the most likely outcome is a default judgment or ex parte award. As a result, types of cases with low consumer response rates are likely also to have a low rate of other (i.e., non-judgment) case dispositions. The next section examines consumer response rates in debt collection cases in arbitration and in court.

\section{CONSUMER RESPONSE RATE}

A commonly expressed concern about debt collection cases in general is that consumers do not appear in court or in arbitration to defend against the claim. Indeed, the AAA has stated that a low response rate in its debt collection program arbitrations was an important reason why it imposed a moratorium on its administration of such cases. ${ }^{65}$ Consumer response rates may also explain the rate of other (non-judgment and non-awarded) case dispositions, as discussed in the previous section.

Calculating the rate at which consumers respond in court and in arbitration is subject to the same difficulties described in the previous section: in some cases, such as dismissals sought by the creditor in court, it can be difficult if not impossible to determine whether the consumer in fact responded to the case. Accordingly, Table 6 reports consumer response rates as a range of percentages. The lower figure for each venue is the percentage of cases in which we have a high degree of confidence that the

63. Fed. Trade Comm'n, Matter No. P094806, Debt Collection: Protecting Consumers 106 (Aug. 5, 2009) (statement of Julie Nepveu, "I have talked to attorneys that say to me when someone shows up to court to defend a lawsuit, they do get dismissed, and they file it again at another time and hope to catch the person out of court one day and default them. It's not unheard of and it's very common in certain jurisdictions.”), available at http://www.ftc.gov/bcp/workshops/debtcollectround/ 090805-CHIL/transcript-90805.pdf.

64. And by definition they have no effect on the recovery rates, because recovery rates are calculated only for cases with prevailing creditors.

65. Fed. Trade Comm’n, Matter No. P094806, Debt Collection: Protecting Consumers 33 (Aug. 6, 2009) (statement of Richard Naimark, “[c]onsumer debt claim collection cases are fairly dramatically different in form. For instance-and I think perhaps this is maybe the most significant issue, and we heard a lot about it yesterday also in the court process - extraordinarily high rates of nonappearance or nonparticipation by consumers, maybe going over 90 percent, extremely high rates of nonparticipation, which creates a systemic problem.”), available at http://www.ftc.gov/bcp/ workshops/debtcollectround/090805-CHIL/transcript-90806.pdf. 
consumer in fact did appear-because there is evidence the case settled, the consumer in fact filed a response in the proceeding, and so forth. Uncertain cases are classified as cases in which the consumer did not appear. The higher figure is the percentage of cases in which the consumer might have appeared. Uncertain cases are classified as cases in which the consumer did appear. Thus, the range sets out the minimum and maximum consumer response rates in the debt collection cases studied.

The consumer response rate in the individual AAA debt collection arbitrations we studied is substantially higher than the consumer response rate in the other types of cases, regardless of how the rate is defined. Conversely, the consumer response rate in the AAA debt collection program arbitrations is lower than the consumer response rate for the other types of cases, almost without exception. The consumer response rate in the court cases is in between.

Table 6: Consumer Response Rates in Arbitration and in Court, Claims Brought by Creditors

\begin{tabular}{|c|c|c|c|}
\hline Venue & $\begin{array}{c}\text { Total Cases with } \\
\text { Consumer } \\
\text { Respondent } \\
\text { Response } \\
\end{array}$ & $\begin{array}{l}\text { Total Cases } \\
\text { with Notice }\end{array}$ & $\begin{array}{c}\text { \% of Consumer } \\
\text { Respondent } \\
\text { Responses }\end{array}$ \\
\hline Individual AAA Debt Collection Arbitrations & $69-83$ & 105 & $65.7 \%-79.0 \%$ \\
\hline AAA Debt Collection Program Arbitrations & $363-2,821$ & 19,016 & $1.9 \%-14.8 \%$ \\
\hline Federal Court Student Loan Collection Cases & N/A & N/A & N/A \\
\hline Oklahoma State Court Cases, Claims $<\$ 10,000$ & $50-93$ & 375 & $13.3 \%-24.8 \%$ \\
\hline Oklahoma State Court Cases, Small Claims & $84-121$ & 294 & $28.6 \%-41.2 \%$ \\
\hline Virginia State Court Cases & $18-91$ & 261 & $6.9 \%-34.9 \%$ \\
\hline
\end{tabular}

These findings support the AAA's perception of a low consumer response rate in its debt collection program arbitrations. Possible explanations for the lower response rate in the AAA debt collection program arbitrations than in the court cases studied are: (1) the low amount at stake in the cases; (2) the age of the debt; (3) the type of debt involved; and (4) the identity of the claimant - a third party debt buyer rather than the original debtor. Each of those factors likely provides at least a partial explanation. But the response rate data are sufficiently uncertain that attempts to control for those factors using regression analysis are likely to be unreliable. Another possibility that has been suggested is that consumers do not recognize communications from arbitration providers (as opposed to courts) as important, and so fail to respond. ${ }^{66}$ Again, we cannot test for this possibility. The response rate in the individual AAA consumer arbitrations, however, which is higher than in the court cases studied, does suggest that consumer response rates are not inherently poor in arbitration, and that other factors, such as those discussed above, do play a role.

66. Fed. Trade Comm’n, Matter No. P094806, supra note 65, at 34 (statement of Paul Bland); see also FED. TRADE COMM’N, REPAIRING A BROKEN SYSTEM, supra note 1, at 57. 


\section{REGRESSION ANALYSIS}

As discussed above, the cases in the sample are all debt collection cases, and thus are roughly comparable as a general matter. ${ }^{67}$ A limitation of the results in the previous part is that they do not control for differences among the cases as to the amount claimed by the creditor, whether the consumer respondent failed to appear, the type of creditor, and so on. This part attempts to control for those differences using standard multivariate techniques. Data for the regressions were compiled from the data sources described previously, and the findings in this part are subject to the same limitations. ${ }^{68}$

After controlling for identifiable differences among the cases, our results appear consistent with the results in the previous part. First, the analyses suggest that creditors win at a lower rate (i.e., that consumers fare better) in the arbitrations studied than in court. That finding holds both for individual AAA debt collection arbitrations and for AAA debt collection program arbitrations. Second, we find no statistically significant difference in the percent recovered by prevailing creditors between the arbitrations and court cases studied. ${ }^{69}$

\section{A. DESCRIPTION OF THE DATASET}

We used information from cases with awards or judgments ${ }^{70}$ in individual AAA debt collection arbitrations, AAA debt collection program arbitrations, federal student loan collection cases, and the state court debt collection cases in Oklahoma to construct the dataset used in the regressions. For the AAA debt collection program arbitrations, we used a random sample of 300 awarded cases (rather than the entire 16,500 awarded cases) to make the sample more comparable in size to the samples of cases from the other venues. ${ }^{71}$ Because the amount demanded was not available for the Virginia state court cases, we could not include those cases in the dataset. The final dataset contains 1,139 cases.

We then created variables for whether the creditor claimant won the case, whether the case ended with a default judgment or ex parte award, the amount demanded by the creditor, and the percentage of the amount sought

67. See supra Part II.

68. See supra notes $17-18$ and accompanying text.

69. The models in this part are designed to test whether the results from the previous part hold after controlling for some identifiable differences among the cases.

70. Excluding consent or agreed judgments or awards.

71. The results in Tables 1, 3, and 4 (for the entire population of AAA debt collection program arbitrations) generally hold for the sample of 300 such cases used in the regressions (the number of contested cases in the sample was too small to replicate Table 2). In other words, we have every reason to believe the sample is representative of the population as a whole. 
that the creditor was awarded. Indicator variables ${ }^{72}$ for the venue type (i.e., whether the case was resolved in individual AAA debt collection arbitration, AAA debt collection program arbitration, or court) and for the creditor type (i.e., whether the creditor was the government, a bank or other lender, a service provider such as a law firm or accounting firm, or a debt buyer) were also developed.

\section{B. CREDitOR Wins}

We first examined the relationship between arbitration and the likelihood the creditor wins the case. The CREDITOR WIN variable can only take the values of 0 and 1 , and we chose to use standard linear regressions for our models. ${ }^{73}$ The key variables are the arbitration variables (VENUE_ARB_PROGRAM, VENUE_INDIV_ARB, and VENUE_ALL_ $A R B)$, which measure the likelihood that creditors win in arbitration relative to court. ${ }^{74}$ A positive coefficient indicates that creditors are more likely to win in arbitration than in court (i.e., that consumers fare better in court). A negative coefficient indicates that creditors are less likely to win in arbitration (i.e., that consumers fare better in arbitration). We included a set of controls for whether the judgment or award was entered by default, the amount claimed by the creditor, and the type of creditor claimant. ${ }^{75}$ Our results appear in Table 7 below. ${ }^{76}$

Model 1 in Table 7 suggests that a creditor claimant has a lower likelihood of winning in arbitration than in court (statistically significant at the 1 percent level). Specifically, the fact that a case is decided in arbitration decreases the likelihood of a creditor win by about 3.1 percent as compared to a case heard in court, after controlling for default by the

72. Indicator variables are those that take the values 0 and 1 only.

73. Justification for use of the linear probability model in situations with discrete dependant variables can be found in James J. Heckman \& James M. Snyder, Linear Probability Models of the Demand for Attributes with an Empirical Application to Estimating the Preferences of Legislators 1-5 (Nat'l Bureau of Econ. Research, Working Paper No. W5785 1996), available at http://ssrn.com/ abstract $=4607$. However, our results are also generally robust to logit and probit models.

74. Because the central debate focuses on how outcomes in arbitration compare to outcomes in the likely alternative venue (i.e., court), many of our analyses group all AAA debt collection arbitrations together and separately group all debt collection cases in court together for purposes of comparison. Certainly, each court and each type of AAA arbitration have different outcomes, so it is possible that different types of debt collection arbitrations are better suited for comparison to debt collection cases in certain courts. That analysis is left to other scholars.

75. Because the Virginia cases cannot be included, all bank claimants in the remaining cases win so there is no variation to exploit. As such, the set of indicator variables for creditor claimant type for these models include only the government, service providers, and debt buyers. To prevent the perfect collinearity that would be caused by including all three creditor type indicator variables, we dropped the variable that indicated whether a case was brought by a debt buyer due to its high correlation to the arbitration venue.

76. There is likely some multicollinearity in these models due to the relationships between the venues and creditor claimant types. As such, the results should be interpreted with caution. 
consumer, the amount claimed by the creditor, and the type of creditor claimant. Note that one of the strongest factors contributing to a creditor claimant win is whether the consumer failed to appear such that the judgment or award was by default (RESP_DEFAULT). ${ }^{77}$ By comparison, the type of creditor claimant does not seem to have an effect on the likelihood of a creditor win. Model2 in Table 7 shows that VENUE_ALL_ARB continues to be significant at the five percent level even after controlling for the possibility that observations within each venue are correlated in such a way that causes correlation in the modeling errors associated with venue.

Model 3 in Table 7 is identical to Model 1 except that it separates out the effects of individual AAA debt collection arbitrations and AAA debt collection program arbitrations, rather than combining them in a single arbitration variable. For both types of cases, the fact that the case is decided in arbitration as opposed to court has a statistically significant negative effect on the likelihood a creditor will win. Again, default judgments are important and statistically significant indicators of whether a creditor claimant will win, and creditor type seems to have no statistical effect.

Table 7: OLS Regressions, Creditor Wins as the Dependent Variable

\begin{tabular}{|c|c|c|c|c|c|c|}
\hline $\begin{array}{l}\text { Dependent Wariable = } \\
\text { Creditor win }\end{array}$ & $\begin{array}{r}\text { OLS } \\
\text { All Arb. }\end{array}$ & (1) & $\begin{array}{r}\text { OLS } \\
\text { All Arb. and } \\
\text { Clustered Errors }\end{array}$ & & $\begin{array}{r}\text { OLS } \\
\text { Individual Arb. } \\
\text { and Arb. Program } \\
\end{array}$ & (3) \\
\hline venue_all_arb & $\begin{array}{r}-0.031 \\
(0.011) \\
\end{array}$ & $* * *$ & & & & \\
\hline venue_indv_arb & & & & & $\begin{array}{r}-0.061 \\
(0.036) \\
\end{array}$ & * \\
\hline venue_arb_program & & & & & $\begin{array}{r}-0.025 \\
(0.009) \\
\end{array}$ & $* * *$ \\
\hline resp_default & $\begin{array}{r}0.121 \\
(0.036) \\
\end{array}$ & $* * *$ & $\begin{array}{r}0.127 \\
(0.043) \\
\end{array}$ & $* *$ & $\begin{array}{r}0.114 \\
(0.036) \\
\end{array}$ & $* * *$ \\
\hline log_demand_amt & $\begin{array}{r}-0.006 \\
(0.005) \\
\end{array}$ & & $\begin{array}{r}-0.005 \\
(0.005) \\
\end{array}$ & & $\begin{array}{r}-0.004 \\
(0.003) \\
\end{array}$ & \\
\hline creditor_govt & $\begin{array}{r}0.006 \\
(0.008) \\
\end{array}$ & & & & $\begin{array}{r}0.004 \\
(0.007) \\
\end{array}$ & \\
\hline creditor_service & $\begin{array}{r}-0.010 \\
(0.013) \\
\end{array}$ & & & & $\begin{array}{r}-0.002 \\
(0.008) \\
\end{array}$ & \\
\hline constant & $\begin{array}{r}0.932 \\
(0.049) \\
\end{array}$ & $* * *$ & $\begin{array}{r}0.917 \\
(0.052) \\
\end{array}$ & $* * *$ & $\begin{array}{r}0.917 \\
(0.044) \\
\end{array}$ & $* * *$ \\
\hline Standard Errors & Robust & & $\begin{array}{r}\text { Robust and } \\
\text { Clustered on } \\
\text { venue } \\
\end{array}$ & & Robust & \\
\hline Sample Size & 1,139 & & 1,139 & & 1,139 & \\
\hline R-Squared & 0.099 & & 0.098 & & 0.100 & \\
\hline
\end{tabular}

$* * *=1 \%$ significance level, $* *=5 \%$ significance level, $*=10 \%$ significance level

Standard errors in parentheses

77. Using our data, we cannot determine whether defaulting consumers lose because they do not show up, or whether they do not show up because they have a weak case and are likely to lose anyway. 
Generally, these models seem to confirm our results from Part III. After controlling for differences among the cases, the fact that a case is heard in arbitration appears to be associated with a decreased likelihood of a creditor win (i.e., consumers fare better in the AAA debt collection arbitrations studied than in court). These results hold for AAA debt collection arbitrations in the aggregate, as well as for individual AAA debt collection arbitrations and AAA debt collection program arbitrations separately.

\section{CREDITOR RECOVERY RATE}

We also examined the relationship between arbitration and the percentage of the amount claimed that was awarded to a prevailing creditor. The CREDITOR RECOVERY RATE variable is a percentage with most of the data clustered at one-hundred percent, and we chose to use standard linear models for the regressions. ${ }^{78}$ Again, the key variables are the arbitration variables (VENUE_ARB_PROGRAM, VENUE_INDV_ARB, and VENUE_ALL_ARB), which measure the recovery rate for prevailing creditors in arbitration relative to court. A positive coefficient indicates that creditors are likely to recover a higher percentage of the amount claimed in the arbitrations studied than in court. A negative coefficient indicates that creditors are likely to recover a lower percentage of the amount claimed in the arbitrations studied. We included the same set of controls as in the previous set of regressions, but added CREDITOR_BANK because it does vary in these models. These models contain only 1,117 observations because we only considered cases in which the creditor won. Our results appear in Table 8 below.

In Table 8, the combined arbitration variable has a negative sign and is not statistically significant. In other words, in the cases studied, creditors recovered a lower percentage of the amount sought in arbitration than in litigation, but we cannot say that the venue has any statistical effect on the creditor recovery rate. When individual AAA debt collection arbitrations are considered separately from AAA debt collection program arbitrations again neither variable is statistically significant, although the coefficients have a negative sign. In both Model 1 and Model 3, the fact that a creditor is a service provider (e.g., a law firm or accounting firm) has a statistically significant negative relationship to the creditor recovery rate at the one percent and five percent levels. This finding is to be expected: consumers likely have a greater ability to challenge the amounts billed by law firms and accounting firms than they do credit card debts or debts acquired by debt buyers. The fact that a bank is a creditor also has a statistically significant negative relationship to the recovery rate, although both the

78. Generalized linear models (GLM) with logit links produce similar results to those in Table 8. 
magnitude of the effect and its statistical significance are lower. Again, this finding is unsurprising since consumers likely can more readily challenge debts owed to banks than the older debts acquired by debt buyers. Government creditors also have a statistically significant negative relationship to the recovery rate as compared to debt buyers.

Table 8: OLS Regressions, Creditor Recovery Rate as the Dependent Variable

\begin{tabular}{|c|c|c|c|c|c|}
\hline $\begin{array}{l}\text { Dependent Wariable = } \\
\text { Creditor Recovery Rate }\end{array}$ & $\begin{array}{l}\text { OLS } \\
\text { All Arb. }\end{array}$ & & $\begin{array}{r}\text { OLS } \\
\text { All Arb. and } \\
\text { Clustered Errors }\end{array}$ & $\begin{array}{r}\text { OLS } \\
\text { Individual Arb. } \\
\text { and Arb. Program }\end{array}$ & \\
\hline venue_all_arb & $\begin{array}{r}-0.010 \\
(0.007)\end{array}$ & $* * *$ & $\begin{array}{l}-0.000 \\
(0.013)\end{array}$ & & \\
\hline venue_indv_arb & & & & $\begin{array}{l}-0.036 \\
(0.025)\end{array}$ & \\
\hline venue_arb_program & & & & $\begin{array}{r}-0.0015 \\
(0.005)\end{array}$ & \\
\hline resp_default & $\begin{array}{r}0.014 \\
(0.015)\end{array}$ & & $\begin{array}{c}0.034 \\
(0.016))\end{array}$ & $\begin{array}{r}0.009 \\
(0.014)\end{array}$ & \\
\hline log_demand_amt & $\begin{array}{r}0.002 \\
(0.003) \\
\end{array}$ & & $\begin{array}{r}0.003 \\
(0.003) \\
\end{array}$ & $\begin{array}{r}0.004 \\
(0.003) \\
\end{array}$ & * \\
\hline creditor_govt & $\begin{array}{r}-0.009 \\
(0.005)\end{array}$ & * & & $\begin{array}{l}-0.008 \\
(0.005)\end{array}$ & * \\
\hline creditor_bank & $\begin{array}{r}-0.014 \\
(0.007)\end{array}$ & $* *$ & & $\begin{array}{r}-0.008 \\
(0.007)\end{array}$ & \\
\hline creditor_service & $\begin{array}{r}-0.049 \\
(0.015) \\
\end{array}$ & $* * *$ & & $\begin{array}{r}-0.038 \\
(0.016) \\
\end{array}$ & $* *$ \\
\hline constant & $\begin{array}{r}0.974 \\
(0.024) \\
\end{array}$ & $* * *$ & $\begin{array}{rr}0.932 & \\
(0.027) & * * * \\
\end{array}$ & $\begin{array}{r}0.954 \\
(0.025) \\
\end{array}$ & $* * *$ \\
\hline Standard Errors & Robust & & $\begin{array}{r}\text { Robust and } \\
\text { Clustered on } \\
\text { venue }\end{array}$ & Robust & \\
\hline Sample Size & 1,117 & & 1,117 & 1,117 & \\
\hline R-Squared & 0.039 & & 0.010 & 0.042 & \\
\hline
\end{tabular}

Generally, these models again seem to confirm our results from Part III. After controlling for differences among the cases, we do not find any statistically significant difference in creditor recovery rate due to the case being resolved in arbitration rather than in court. ${ }^{79}$

Because creditors may select into certain venues, our results may be subject to selection bias. In an attempt to test the robustness of our results, we performed several other analyses, including the use of a propensity score estimator and propensity score matching. Both of these analyses can be used to determine the average effect of going to arbitration (VENUE_ALL_ARB) on the creditor win rate and the prevailing creditor recovery rate while attempting to control for non-random selection into arbitration.

79. As noted above, see supra text accompanying note 66, the consumer response rate data are too uncertain to attempt regression analysis using that data. 
The propensity score estimator was constructed by first running a probit model for VENUE_ALL_ARB on whether the consumer defaulted, the demand amount, and controls for debt buyer and service provider creditors, and then calculating the predicted values in STATA, which are used as the propensity scores. The propensity scores were then used with VENUE_ALL_ARB in OLS regressions with CREDITOR WIN and CREDITOR RECOVERY RATE as dependent variables respectively.

We constructed the average treatment effect (ATE) of VENUE_ALL_ARB on CREDITOR WIN and CREDITOR RECOVERY $R A T E$ respectively by matching on the propensity score variable discussed above. We used four matches as suggested by Abadie et al. "because it offers the benefit of not relying on too little information without incorporating observations that are not sufficiently similar." 80

Table 9 shows that regardless of the model used, VENUE_ALL_ARB has a similar relationship to CREDITOR WIN and CREDITOR RECOVERY $R A T E$ respectively. This finding provides some confidence in our initial linear models.

Table 9: Comparison of the Coefficient on VENUE_ALL_ARB

\begin{tabular}{|r|cc|cr|}
\hline & \multicolumn{2}{|l|}{$\begin{array}{l}\text { Dependent Variable } \\
\text { Creditor win }\end{array}$} & \multicolumn{2}{c|}{$\begin{array}{c}\text { Dependent Variable }= \\
\text { Creditor Recovery Rate }\end{array}$} \\
\hline Model & Coefficient & $\begin{array}{c}\text { Std. } \\
\text { Error }\end{array}$ & Coefficient & $\begin{array}{r}\text { Std. } \\
\text { Error }\end{array}$ \\
\hline OLS, Robust Errors & -0.031 & $0.011 * * *$ & -0.010 & 0.007 \\
OLS, Robust Errors Clustered on VENUE & -0.032 & $0.008 * *$ & -0.000 & 0.013 \\
OLS, Robust Errors, Propensity Score Estimator & -0.025 & $0.014 *$ & -0.009 & 0.007 \\
Matching, ATE with 4 Matches, Robust Errors & -0.035 & $0.010 * * *$ & -0.015 & 0.011 \\
\hline$* * *=1 \%$ significance level, ** $*$ 5\% significance level, * $=10 \%$ significance level & &
\end{tabular}

\section{CONCLUSIONS}

This article examines how consumers fare in debt collection cases in arbitration and in court. It compares how often creditors win and the extent to which creditors are awarded the amount originally sought in AAA debt collection arbitrations as well as in debt collection cases in state and federal courts. It also looks at the extent to which debt collection cases are disposed of other than by award or judgment, and how often consumers respond (and fail to respond).

As a general matter, in the cases we studied, consumers fared at least as well in arbitration as in court. After controlling for differences among the cases, we found that creditors had a lower likelihood of prevailing (i.e., consumers were more likely to win) in the AAA debt collection arbitrations studied than in court. When creditors did prevail, we found no statistical

80. Alberto Abadie et al., Implementing Matching Estimators for Average Treatment Effects in STATA, 4 STATA J. 290, 298 (2004). 
difference in the amount they were awarded as a percentage of the amount sought in AAA debt collection arbitrations as compared to court. To the extent that consumers fared better in the AAA arbitrations studied than in the court cases studied, it may well be that differences in case characteristics for which we were not able to control explain the differences. Thus, we do not claim that arbitration outcomes are better for consumers than outcomes for comparable cases in court. Nonetheless, at a minimum, these findings should dispel the notion that high creditor win rates and recovery rates in debt collection arbitrations show that arbitration is unfair to consumers. Creditor win rates and recovery rates were as high or higher in the court cases we studied. Moreover, these findings provide no support for any claim that AAA debt collection arbitrations are biased in favor of creditors. Consumers fared at least as well in AAA debt collection arbitrations as in the court cases we studied. ${ }^{81}$

The results are mixed when it comes to rates of other dispositions and consumer response rates. We found no systematic differences between arbitration and litigation in the disposition of debt collection cases other than by award or judgment. As for consumer response rates, in the individual AAA debt collection cases we studied, consumers responded at a higher rate than in the court cases we studied. In the AAA debt collection program arbitrations we studied, consumers responded at a lower rate than in the court cases we studied. Our finding of relatively low response rates in the AAA debt collection program arbitrations is consistent with an important reason given by the AAA for imposing a moratorium on administering such arbitrations: the low rate at which consumers appeared and contested the claim. But as with win rates and recovery rates, these findings suggest that the consumer response rates may be due to characteristics of debt collection cases rather than the venue-court or arbitration-in which those cases are resolved.

As discussed above, our findings are subject to several limitations. First, the findings on arbitration are limited to AAA debt collection arbitrations. Empirical results from studying AAA debt collection arbitrations do not necessarily apply to other types of arbitration or other arbitration providers. But as we have indicated elsewhere, in setting national policy concerning arbitration, information on consumer arbitrations administered by the AAA, a leading provider of arbitration services, certainly is necessary for making an informed decision. ${ }^{82}$ Second, our findings on debt collection actions in court necessarily are limited to the courts studied. That said, our findings appear broadly consistent with

81. These findings also suggest the possibility that consumers may not be better off having their debt collection claims resolved in court than in arbitration (at least arbitrations as administered by the AAA).

82. SeARLE Civil JUSTICE INST., supra note 9, at 3. 
previous studies of debt collection cases in court. ${ }^{83}$ Third, to the extent we focus on court judgments and arbitration awards, differential settlement rates among the venues might bias our results. Fourth, cases are not selected into arbitration randomly; thus, finding truly comparable cases between court and arbitration is extremely difficult. Indeed, the fact that one set of cases is selected into arbitration while the other is selected into court is itself a difference for which we cannot fully control. That said, to the extent "there now appears to be a consensus that the future of arbitration should be decided by data, not anecdote," ${ }^{84}$ this article contributes additional data to the policy debate.

\section{APPENDIX A. PROCEDURES IN AAA DEBT COLLECTION PROGRAM ARBITRATIONS ${ }^{85}$}

As a general matter, the AAA administered the debt collection program arbitrations under its Supplementary Procedures for the Resolution of Consumer-Related Disputes ${ }^{86}$ and the Consumer Due Process Protocol. ${ }^{87}$ The procedures differed from the procedures in the individual AAA debt collection arbitrations we studied, however, in several significant ways.

First, the AAA charged reduced fees to the creditor and to consumers in the debt collection program arbitrations, and staggered those fees throughout the arbitration process. ${ }^{88}$ For example, under the AAA's consumer procedures, a consumer would have to pay his or her share of the arbitrator's fees ( $\$ 125$ for claims seeking $\$ 10,000$ or less) to proceed with a claim or counterclaim. ${ }^{89}$ For AAA debt collection program arbitrations, the fee was reduced to $\$ 50$. In addition, the fee charged to the creditor was staggered over the course of the arbitration: only a portion of the total fee was due on filing of the claim, with additional amounts due the further the claim proceeded through the arbitration process.

83. See sources cited supra note 18

84. Peter B. Rutledge, Common Ground in the Arbitration Debate, 1 Y.B. ARB. \& MEdiation 1, 8 (2009) (emphasis omitted).

85. The descriptions in this appendix are based on discussions with AAA personnel knowledgeable about the program, and are consistent with our observations from reviewing a sample of electronic case files.

86. Consumer-Related Disputes Supplementary Procedures, AMERICAN ARBITRATION Association, (rules effective Sept. 15, 2005), http://www.adr.org/sp.asp?id=22014 [hereinafter AAA Consumer Rules].

87. National Consumer Disputes Advisory Committee, Consumer Due Process Protocol, AMERICAN ARBITRATION AsSOCIATION (April 17, 1998), www.adr.org/sp.asp?=22019.

88. The reduced fees were possible because the electronic system the AAA used to administer the arbitrations resulted in lower administrative and processing costs. Cost savings came from electronic data and document transfer, a pre-screened pool of arbitrators, use of desk arbitration, and automating document handling.

89. AAA Consumer Rules, supra note 86 ("Fees and Deposits to Be Paid by the Consumer"). 
Second, although a fee was assessed against a consumer who asserted a counterclaim, the AAA would upload directly to the electronic case file any documents submitted by consumers regardless of whether they paid the required fee.

Third, notice was given differently in the AAA's debt collection program arbitrations. The AAA sent a written, paper initiation letter to the consumer respondent, with electronic transmission to the creditor. Initially, the AAA sent initiation letters to the consumer via certified mail, return receipt requested. ${ }^{90}$ When it became evident that many initiation letters were being returned without being signed for, the AAA switched to mail requiring "delivery confirmation," under which the postal carrier would confirm the date and time the initiation letter was left at the mailing address. After switching to delivery confirmation, the AAA re-mailed initiation letters in cases in which the consumers did not sign for a certified mail delivery.

Fourth, the AAA pre-screened arbitrators to avoid conflicts of interest and to expedite the arbitrator selection process. The AAA identified attorney-arbitrators who were already on an AAA panel and invited them to serve as arbitrators in debt collection program arbitrations. Potential arbitrators filled out a pre-screening questionnaire that enabled the AAA to create a pool of arbitrators who had no relationship with the creditor or any of its parent or related companies. Arbitrators were also asked to agree to serve for reduced fees. The creditor had no involvement in the identification, screening, or training of the arbitrators.

Fifth, arbitrators were selected randomly from the pool of prescreened arbitrators located in the same state as the consumer. ${ }^{91}$ Because the system's software permitted the AAA to rotate through the arbitrators in a given state as cases were filed, case managers did not have to appoint an arbitrator individually in each case.

Sixth, to streamline the awards process, an award template was created. Arbitrators prepared the award by entering data in fields on the template, along with text comments if desired. The template was used to prepare the written award in the case, which was mailed to the consumer respondent and sent electronically to the creditor. The arbitrator was able to affix his or her signature to the award electronically.

The AAA and the creditor took six to nine months to develop the software, set up the electronic file transfer system, and create the capability for case information to be assigned to individual arbitrators and made available to them. Arbitrators were also screened and trained during this time.

90. The creditor had already sent its own notice to the consumer requiring a signed receipt verifying delivery. An electronic copy of that receipt was included with the documents the creditor provided as part of its case filing.

91. Fed. TRAde Comm’N, supra note 65, at 146-47 (statement of Richard Naimark). 


\section{APPENDIX B. DATA VERIFICATION AND CORRECTION FOR AAA DEBT COLLECTION PROGRAM ARBITRATIONS}

Because most information for the AAA debt collection program arbitrations was processed and stored electronically, we were able to use the original electronic files to verify the information for a sample of 408 awarded and non-awarded cases. The cases we reviewed were ones for which we sought more information on what had happened in the case or in which the coded data for the case contained an inconsistency.

We first reviewed the files for 99 non-awarded cases: 19 of the cases were closed administratively; 60 were withdrawn before March 2009 and did not have award dates entered in the database; and 20 were withdrawn, but had award dates entered in the database. We were able to verify the available information in the database for all of the cases except for the 20 withdrawn cases with award dates. In those cases, the award date was entered in error; no award had been made in any of the cases. Note that it was not usually clear from the information in the files why the cases had been withdrawn. Of the 99 case files we examined, 16 (16.2 percent) contained some explanation for the withdrawal or administrative closing. In the majority of those cases ( 9 out of 16 , or 56.3 percent), the case was closed because the consumer respondent had requested that the dispute be resolved in small claims court, as permitted by the Consumer Due Process Protocol.

We then used the electronic case files to verify the information for a sample of 309 awarded cases. For some of the cases, the information in the database appeared inconsistent; for others, we reviewed a random sample of the cases to make sure there were no inconsistencies. Specifically we reviewed:

- 1 case in which the creditor appeared not to have made a claim;

- 17 cases in which creditor appeared to have been awarded over one-hundred percent of the amount claimed;

- 30 cases in which the creditor was listed as the prevailing party but appeared to have been awarded zero percent of the amount claimed;

- 50 cases in which the consumer was listed as the prevailing party and the creditor appeared to have been awarded zero percent of the amount claimed;

- 50 cases in which the creditor was listed as the prevailing party and was awarded one-hundred percent of the amount claimed;

- 3 cases in which the creditor appeared to have been awarded onehundred percent of the amount claimed but in which the prevailing party was listed as the respondent or neither;

- 50 cases in which the consumer was coded as having filed a counterclaim; 
- 50 cases in which the consumer was coded as having participated in the case by submitting at least one letter to the arbitrator;

- 50 cases in which neither party was listed as the prevailing party; and

- 8 cases in which the filing or hearing fees were higher than in the other cases in the sample.

Generally, we could verify most information on the awarded cases in the electronic database using the case files. However, we identified and corrected the following errors in the database:

The creditor made a claim in every case; the one case in which a claim was shown as absent was corrected to show that the creditor was awarded one-hundred percent of the amount claimed.

- The creditor was never awarded more than one-hundred percent of the amount claimed. Instead, in 17 cases, the database incorrectly listed the claim amounts. In those cases, the claim amount was corrected with the result that the creditor was awarded one-hundred percent of the amount claimed.

- According to the AAA, early in the process an error involving the award template resulted in the creditor winning the case but receiving no monetary award. In all 30 of the cases in which that happened in the complete dataset, the arbitrator modified the award to reflect the correct amount awarded, but the coding was not corrected in the original database. We corrected the database to reflect that the claimant was awarded one-hundred percent of its claim in each of these cases.

- The three cases in which the creditor was awarded money but was not listed as the prevailing party were corrected so that the creditor is shown as the prevailing party.

- Arbitrators were not consistent in classifying the prevailing party when the creditor did not prevail. For example, when a claim was rejected for insufficient notice of the arbitration proceeding, some arbitrators recorded the case as one in which neither party prevailed, while other arbitrators recorded the case as one in which the consumer prevailed. To enhance consistency, we recoded the 808 awarded cases in which the creditor was not awarded any monetary amount as follows:

0 If the arbitrator gave insufficient notice as the primary reason for the award, then the case was coded "Neither-Notice"-i.e., neither party prevailed and the claim was dismissed for lack of notice. This coding is analogous to our treatment of cases in which service of process was not made in the court cases we studied. 
o If the arbitrator simply indicated that he or she was dismissing the case generally, then the case was coded "Neither-Dismissed"-i.e., neither party prevailed and the claim was dismissed. In those cases, the dismissal appeared to be without prejudice such that the case could have been refiled.

o Two cases were coded "NA" because the arbitrator did not fill in the award sheet for this category and did not provide notes explaining his or her decision.

o If the case was not in the sample of cases for which we reviewed the electronic case files and the arbitrator did not provide notes explaining his or her decision, then the case was coded consistently with the arbitrator's description (i.e., either the consumer prevailed or neither party prevailed) in the original award document.

o All other cases in which the creditor was not coded as the prevailing party in the original database were coded with the consumer as the prevailing party.

- Finally, it was not always possible to verify whether a consumer participated or filed a counterclaim in the case based on the documents available in the files. Often the file would not contain any documentation from the consumer, but it is possible that there was a communication that did not get placed in the electronic file. In order to be consistent, we re-coded the consumer participation variable based on the arbitrator's notes. Therefore, we coded the consumer participation variable as "yes" when we could definitively verify that the consumer participated in the case; "maybe" when the case was originally coded as the consumer participating but we could not verify that fact in the file; and "no" when the case was originally coded as the consumer did not participate.

The above changes and corrections are included in the results presented in this article. 


\section{APPENDIX C. ERROR RATES IN FEDERAL COURT/AO STUDENT LOAN DATA}

Previous studies have documented systematic errors in the data on federal court cases available from the Administrative Office of the United States Courts (AO) ${ }^{92}$ We likewise identified several systematic errors in the data reported by the $\mathrm{AO}$ on actions seeking collection of unpaid student loans, and corrected those errors before using the data in our analysis.

Two types of inconsistencies were apparent on the face of the data. First, a significant number of observations reported zero values for amounts that almost certainly should have been coded as some non-zero amount. For example, the amount awarded (AMTREC) was often coded as zero, even when the plaintiff was coded as having prevailed by default judgment in the case. ${ }^{93}$ While it is possible that a plaintiff might "prevail" by default judgment and receive no monetary remedy, such cases are likely to be rare, much rarer than found in the uncorrected data.

Second, in a number of cases, when a non-zero amount was reported for either the amount demanded (DEMANDED) or the amount awarded, the amount appeared to be coded incorrectly. The coding instructions for the dataset indicate that the amount demanded and the amount awarded are to be coded in thousands of dollars. ${ }^{94}$ In a number of cases, it appeared that this was not done. For example, in a number of entries, the amount sought or amount awarded was coded as “9999," meaning that the amount sought or awarded against an individual consumer for an unpaid student loan was at least $\$ 9,999,000,{ }^{95}$ an implausibly large amount of student loan debt for someone to incur. Instead, of course, the amount entered was the full amount of the judgment, rather than the amount in thousands of dollars. ${ }^{96}$

A third type of error became apparent when we examined the docket sheets in attempting to correct for the other two types of errors. In coding the amount demanded and the amount awarded, principal and interest on

92. E.g., Eisenberg \& Schlanger, supra note 33, at 1473; Gillian K. Hadfield, Exploring Economic and Democratic Theories of Civil Litigation: Differences Between Individual and Organizational Litigants in the Disposition of Federal Civil Cases, 57 STAN. L. REV. 1275, 1305-1311 (2005); Gillian K. Hadfield, Where Have All the Trials Gone? Settlements, Nontrial Adjudications, and Statistical Artifacts in the Changing Disposition of Federal Civil Cases, 1 J. EMPIRICAL Legal STUD. 705, 72328 (2004).

93. In addition, a substantial percentage of cases $(1,094$ of 1,480 , or $73.9 \%)$ had the amount demanded coded as zero. It is possible that the complaints in those cases did not specify an amount demanded. But given that the cases were seeking recovery of easily quantified student loan debts that seems unlikely. Because we limited our sample to those cases specifying a non-zero amount demanded, none of these cases was included in the sample.

94. Administrative Office of the United States Courts, Technology Training \& Support Division, Civil Statistical Reporting Guide ver. 2.1 07/1999 at 3:9, 3:21 (July 1999).

95. Only four digits were available for coding these amounts, so that the largest figure that could be entered was 9999 .

96. This error is particularly significant when calculating percent recoveries. 
the loan were often treated inconsistently. In some cases, the amount demanded included both principal and interest, while the amount awarded included only the principal, or vice versa.

Other types of coding errors, while occurring, were less common, although still potentially significant. Several cases had errors in the coding of the case disposition (DISP), most commonly default judgments coded as a different disposition. Three cases in the sample had the prevailing party (JUDGMENT) coded improperly - two incorrectly coded as consumer wins, and one incorrectly coded as a default judgment for the government (the default judgment was later vacated and the case dismissed). ${ }^{97}$

Overall, 171 of the 382 cases in the sample (or 44.8 percent) contained at least one of these types of coding errors. As noted previously, we corrected these errors before using the data in our analysis. The frequency of the various types of coding errors is summarized in Table C.1:

Table C.1: Coding Errors in Student Loan Collection Cases in Federal Court / AO Data

\begin{tabular}{|lcc|}
\hline Variable Coding Error & Frequency of Error & $\begin{array}{c}\text { Frequency as a Percent of } \\
\text { Cases in Sample (N = 382)* }\end{array}$ \\
\hline Amount Demanded (DEMANDED) & 10 & $\mathbf{2 . 6 \%}$ \\
Not coded in thousands & 19 & $\mathbf{5 . 0 \%}$ \\
Principal/interest & & $\mathbf{1 1 . 8 \%}$ \\
Amount Awarded (AMTREC) & 45 & $\mathbf{1 0 . 2 \%}$ \\
Coded as zero & 39 & $\mathbf{1 5 . 7 \%}$ \\
Not coded in thousands & 60 & $\mathbf{0 . 5 \%}$ \\
Principle/interest & 2 & $\mathbf{5 . 0 \%}$ \\
Missing data & & $\mathbf{0 . 8 \%}$ \\
Disposition (DISP) & 19 & \\
Mudgment (JUDGMENT) & 3 & \\
Miscoded & & \\
*The total number of errors exceeds the total number of cases with errors because twenty cases had two coding
\end{tabular}
errors and three cases had three errors.

97. To take account of the possibility that our sample might be somehow biased against cases resulting in wins by the consumer, we reviewed the entire sample of student loan cases (i.e., including those with zero coded as the amount demanded) for cases coded as consumer wins. Out of the 1,480 student loan cases, 12 (or less than $1 \%$ ) were coded as wins for the consumer. When we examined the docket sheets and files for those 12 cases, however, all of them were coded incorrectly. None actually was a win for the consumer: either the cases were not properly classified as student loan cases, or they in fact involved consent or default judgments in favor of the government. 


\section{APPENDIX D. CASE OUTCOMES FOR CREDITOR CLAIMS: SUMMARY TABLES}

Table D.1: Outcomes in Individual AAA Debt Collection Arbitrations*

\begin{tabular}{|c|c|c|}
\hline Outcome Classification & $\begin{array}{c}\text { Number of } \\
\text { Cases }\end{array}$ & Total Cases \\
\hline \multicolumn{3}{|l|}{ Awarded Cases } \\
\hline \multicolumn{3}{|l|}{ Creditor Claimant Wins } \\
\hline Cases with consumer responses & 28 & \\
\hline Cases without consumer responses (ex parte awards) & 22 & \\
\hline Total Creditor Claimant Wins & 50 & \\
\hline \multicolumn{3}{|l|}{ Consumer Respondent Wins } \\
\hline Cases with consumer responses & 8 & \\
\hline Cases without consumer responses (ex parte awards) & 0 & \\
\hline Total Consumer Respondent Wins & 8 & \\
\hline Total Awarded Cases & & 58 \\
\hline \multicolumn{3}{|l|}{ Other Case Dispositions } \\
\hline Cases without Consumer Responses & 0 & \\
\hline \multicolumn{3}{|l|}{ Cases with Consumer Responses } \\
\hline Settlements & 32 & \\
\hline Consent awards & 1 & \\
\hline Total Cases with Consumer Responses & 33 & \\
\hline \multicolumn{3}{|l|}{ Cases with Possible Consumer Responses } \\
\hline Cases closed administratively & 5 & \\
\hline Withdrawals & 9 & \\
\hline Total Cases with Possible Consumer Responses & 14 & \\
\hline Total Other Case Dispositions & & 47 \\
\hline Grand Total Individual AAA Debt Colle & Arbitrations & 105 \\
\hline
\end{tabular}

*The number of awarded cases differs slightly from the number reported in the Preliminary Report because we excluded three contested cases (two consumer wins; one business win) that likely should not be treated as debt collection cases. We do not have sufficient information to make comparable adjustments for non- awarded cases, and so we treated all non-awarded cases with business claimants as debt collection cases. 
Table D.2: Outcomes in AAA Debt Collection Program Arbitrations

\begin{tabular}{|c|c|c|}
\hline Outcome Classification & $\begin{array}{c}\text { Number of } \\
\text { Cases }\end{array}$ & $\begin{array}{l}\text { Total } \\
\text { Cases } \\
\end{array}$ \\
\hline \multicolumn{3}{|l|}{ Awarded Cases } \\
\hline \multicolumn{3}{|l|}{ Creditor Claimant Wins } \\
\hline Cases with consumer responses & 41 & \\
\hline Cases with likely consumer responses & 264 & \\
\hline Cases without consumer responses (ex parte awards) & 15,714 & \\
\hline Total Creditor Claimant Wins & 16,019 & \\
\hline \multicolumn{3}{|l|}{ Consumer Respondent Wins } \\
\hline Cases with consumer responses & 23 & \\
\hline Cases with likely consumer responses & 30 & \\
\hline Cases without consumer responses (ex parte awards) & 428 & \\
\hline Total Consumer Respondent Wins & 481 & \\
\hline Total Awarded Cases & & 16,500 \\
\hline \multicolumn{3}{|l|}{ Other Case Dispositions } \\
\hline \multicolumn{3}{|l|}{ Cases without Consumer Responses } \\
\hline No notice - dismissed & 269 & \\
\hline Dismissed & 4 & \\
\hline Unspecified reason for neither party prevailing & 48 & \\
\hline Prevailing party left blank on award template & 1 & \\
\hline Total Cases without Consumer Responses & 322 & \\
\hline \multicolumn{3}{|l|}{ Cases with Consumer Responses } \\
\hline Dismissed & 1 & \\
\hline Unspecified reason for neither party prevailing & 3 & \\
\hline Prevailing party left blank on award template & 1 & \\
\hline Total Cases with Consumer Responses & 5 & \\
\hline \multicolumn{3}{|l|}{ Cases with Possible Consumer Responses } \\
\hline Cases closed administratively & 19 & \\
\hline Withdrawals prior to $3 / 18 / 2009$ & 2,439 & \\
\hline Total Cases with Possible Consumer Responses & 2,458 & \\
\hline \multicolumn{2}{|l|}{ Total Other Case Dispositions } & 2,785 \\
\hline \multicolumn{3}{|c|}{ Grand Total Individual AAA Debt Collection Program } \\
\hline Arbitrations & & 19,285 \\
\hline
\end{tabular}


Table D.3: Outcomes in Federal Court Student Loan Collection Cases

\begin{tabular}{|c|c|c|}
\hline Outcome Classification & $\begin{array}{c}\text { Number of } \\
\text { Cases }\end{array}$ & $\begin{array}{l}\text { Total } \\
\text { Cases } \\
\end{array}$ \\
\hline \multicolumn{3}{|l|}{ Judgments } \\
\hline \multicolumn{3}{|l|}{ Creditor Claimant Wins } \\
\hline Cases with consumer responses (judgments on pretrial motion) & 11 & \\
\hline Cases without consumer responses (default judgments) & 286 & \\
\hline Total Creditor Claimant Wins & 297 & \\
\hline \multicolumn{3}{|l|}{ Consumer Respondent Wins } \\
\hline \multicolumn{3}{|l|}{ Cases with consumer responses (judgment for creditor vacated; } \\
\hline $\begin{array}{l}\text { case dismissed)* } \\
\text { Cases without consumer responses }\end{array}$ & $\begin{array}{l}1 \\
0\end{array}$ & \\
\hline Total Consumer Respondent Wins & 1 & \\
\hline \multicolumn{2}{|l|}{ Total Awarded Cases } & 298 \\
\hline \multicolumn{3}{|l|}{ Other Case Dispositions } \\
\hline Cases without Consumer Responses & N/A & \\
\hline \multicolumn{3}{|l|}{ Cases with Consumer Responses } \\
\hline Settlements & N/A & \\
\hline Consent awards & 84 & \\
\hline Total Observed Cases with Consumer Responses & 84 & \\
\hline Cases with Possible Consumer Responses & N/A & \\
\hline \multicolumn{2}{|l|}{ Total Other Case Dispositions } & 84 \\
\hline \multicolumn{2}{|c|}{ Grand Total Federal Court Student Loan Collection Cases } & 382 \\
\hline
\end{tabular}

*In that case, the court originally entered a default judgment against the consumer. Later, the default judgment was vacated and the case was dismissed, based on the parties' agreement that the consumer was not liable for the debt. Arguably, the case should not have been included in the sample at all, because the case was terminated in 2008, rather than in the sample period. 
Table D.4.a: Outcomes in Oklahoma State Court Cases, $<\$ \mathbf{1 0 , 0 0 0}$, Creditor Claims

\begin{tabular}{|c|c|c|}
\hline Outcome Classification & $\begin{array}{c}\text { Number of } \\
\text { Cases }\end{array}$ & $\begin{array}{l}\text { Total } \\
\text { Cases }\end{array}$ \\
\hline \multicolumn{3}{|l|}{ Judgments } \\
\hline \multicolumn{3}{|l|}{ Creditor Claimant Wins } \\
\hline Cases with consumer responses (summary judgments) & 8 & \\
\hline Cases without consumer responses (default judgments) & 282 & \\
\hline Total Creditor Claimant Wins & 290 & \\
\hline \multicolumn{3}{|l|}{ Consumer Respondent Wins } \\
\hline Cases with consumer responses (summary judgments) & 1 & \\
\hline Cases with consumer responses (judgment for creditor vacated) & 1 & \\
\hline Cases without consumer responses (default judgments) & 0 & \\
\hline Total Consumer Respondent Wins & 2 & \\
\hline Total Awarded Cases & & 292 \\
\hline \multicolumn{3}{|l|}{ Other Case Dispositions } \\
\hline \multicolumn{3}{|l|}{ Cases without Consumer Responses } \\
\hline No notice - dismissed & 44 & \\
\hline Total Cases without Consumer Responses & 44 & \\
\hline \multicolumn{3}{|l|}{ Cases with Consumer Responses } \\
\hline Settlements & 2 & \\
\hline Bankruptcy filing & 4 & \\
\hline Dismissed after response from consumer & 12 & \\
\hline Agreed judgments & 22 & \\
\hline Total Cases with Consumer Responses & 40 & \\
\hline \multicolumn{3}{|l|}{ Cases with Possible Consumer Responses } \\
\hline Notice but no evidence of consumer response - dismissed & 43 & \\
\hline Total Cases with Possible Consumer Responses & 43 & \\
\hline \multicolumn{2}{|l|}{ Total Other Case Dispositions } & 127 \\
\hline \multicolumn{2}{|l|}{ Grand Total Oklahoma State Court Cases, $<\$ 10,000$} & 419 \\
\hline
\end{tabular}


Table D.4.b: Outcomes in Oklahoma State Court Cases, Small Claims, Creditor Claims

\begin{tabular}{|c|c|c|}
\hline Outcome Classification & $\begin{array}{c}\text { Number of } \\
\text { Cases }\end{array}$ & $\begin{array}{l}\text { Total } \\
\text { Cases }\end{array}$ \\
\hline \multicolumn{3}{|l|}{ Judgments } \\
\hline \multicolumn{3}{|l|}{ Creditor Claimant Wins } \\
\hline Cases with consumer responses (judgments) & 18 & \\
\hline Cases without consumer responses (default judgments) & 173 & \\
\hline Total Creditor Claimant Wins & 191 & \\
\hline \multicolumn{3}{|l|}{ Consumer Respondent Wins } \\
\hline Cases with consumer responses (judgments) & 0 & \\
\hline Cases with consumer responses (judgment for creditor vacated) & 0 & \\
\hline Cases without consumer responses (default judgments) & 0 & \\
\hline Total Consumer Respondent Wins & 0 & \\
\hline Total Awarded Cases & & 191 \\
\hline \multicolumn{3}{|l|}{ Other Case Dispositions } \\
\hline \multicolumn{3}{|l|}{ Cases without Consumer Responses } \\
\hline No notice - dismissed & 36 & \\
\hline Total Cases without Consumer Responses & 36 & \\
\hline \multicolumn{3}{|l|}{ Cases with Consumer Responses } \\
\hline Settlements & 0 & \\
\hline Bankruptcy filing & 1 & \\
\hline Dismissed after response from consumer & 11 & \\
\hline Agreed judgments* & 54 & \\
\hline Total Observed Cases with Consumer Responses & 66 & \\
\hline \multicolumn{3}{|l|}{ Cases with Possible Consumer Responses } \\
\hline Notice but no evidence of consumer response - dismissed & 37 & \\
\hline Total Cases with Possible Consumer Responses & 37 & \\
\hline Total Other Case Dispositions & & 139 \\
\hline Grand Total Oklahoma State Court Cases, Smal & aims & 330 \\
\hline
\end{tabular}

*We coded as agreed judgments all cases in which the consumer appeared in small claims court and signed a judgment setting out a payment schedule for paying off the debt. It is possible, but seems unlikely, that in those cases the court ruled in favor of the creditor in a contested case, and only after the ruling did the parties work out a payment schedule. If so, then some proportion of the agreed judgments would need to be reclassified as judgments in favor of the creditor. 
Table D.5: Outcomes in Virginia State Court Cases (Warrant in Debt), Business Claimants

\begin{tabular}{|c|c|c|}
\hline Outcome Classification & $\begin{array}{c}\text { Number of } \\
\text { Cases }\end{array}$ & $\begin{array}{l}\text { Total } \\
\text { Cases } \\
\end{array}$ \\
\hline \multicolumn{3}{|l|}{ Judgments } \\
\hline \multicolumn{3}{|l|}{ Creditor Claimant Wins } \\
\hline Cases with consumer responses (judgments) & 15 & \\
\hline Cases without consumer responses (default judgments) & 170 & \\
\hline Total Creditor Claimant Wins & 185 & \\
\hline \multicolumn{3}{|l|}{ Consumer Respondent Wins } \\
\hline Cases with consumer responses (judgments) & 2 & \\
\hline Cases with consumer responses (judgment for creditor vacated) & 1 & \\
\hline Cases without consumer responses (default judgments) & 0 & \\
\hline Total Consumer Respondent Wins & 3 & \\
\hline Total Awarded Cases & & 188 \\
\hline \multicolumn{3}{|l|}{ Other Case Dispositions } \\
\hline \multicolumn{3}{|l|}{ Cases without Consumer Responses } \\
\hline No notice & 22 & \\
\hline Total Cases without Consumer Responses & 22 & \\
\hline \multicolumn{3}{|l|}{ Cases with Possible Consumer Responses } \\
\hline Nonsuit & 22 & \\
\hline Unspecified dismissal & 51 & \\
\hline Total Cases with Possible Consumer Responses & 73 & \\
\hline Total Other Case Dispositions & & 95 \\
\hline Grand Total Virginia State Court Cases, Warrar & Debt & 283 \\
\hline
\end{tabular}

